\title{
DENSITY MODEL FOR THE CENTRAL PART OF PARANÁ BASIN, USING MAGNETOTELLURICS AS BASEMENT CONSTRAINT, SOUTH PORTION OF BRAZIL
}

\author{
Victor Ribeiro Carreira, Emanuele Francesco La Terra and Sergio Luiz Fontes
}

\begin{abstract}
This article presents a geological-geophysical model along the $320 \mathrm{~km}$ NW-SE profile at the central region of the Paraná basin, based primarily on a 2D gravity model that complements the magnetotelluric (MT) field campaigns conducted by the Agência Nacional do Petróleo, Gás Natural e Biocombustíveis (ANP National Agency of Petroleum, Natural Gas and Biofuels - Brazil). Studies of large structures within the basement underneath a sedimentary basin are of vital importance for the understanding of its tectonic-stratigraphic evolution. The Paraná basin has a depocenter, reaching approximately $7000 \mathrm{~m}$ in estimated depth. Two large regional structures are remarkable in the study area: the Ponta Grossa Arch, NW-SE direction feature; and a NW-SE gravimetric high anomaly. The region also includes great lava flows represented by basalt rocks of the Serra Geral Formation. Intrusion of dikes and sills of diabase, dating mainly from the Cretaceous that equally strikes the region. A regional model was created by a $40 \mathrm{~km}$ wavelength filtering process, used to estimate the limit of the upper mantle-lower crust, and the limit upper crust/lower crust. The cutoff value was calculated by considering the deep sources of the radial power spectrum of the area. The proposed final gravimetric model includes the regional topography and presents a fit, with an error of 1,229 mGal. Its shallowest part was obtained by analyzing data from six stratigraphic wells and by integrating a $1 \mathrm{D}$ magnetotelluric composed section. The deepest structures of the model were connected from studies of deep seismic refraction, receptor function analysis, and surface waves dispersion, in particular the Moho depth from previous studies conducted on the Basin. Tests with synthetic MT models support the proposed geologicalgeophysical model, which presents some notable characteristics: a smooth lower crust-upper mantle interface, which oscillates around $42 \mathrm{~km}$ deep. The upper crust was represented, on the final model, by a sedimentary basin and three main crustal blocks, designated as the Paraná River Block, the Paranapanema Block, and the Apiaí Block, in accordance with the geotectonic context. The basin-basement limit, derived from the 1D MT models, revealed a fractured surface with an average depth of $6000 \mathrm{~m}$. The sedimentary portion can be differentiated in its established supersequences, but does not solve the problems posed by dikes and sills.
\end{abstract}

Keywords: radial average power spectrum, gravimetric inversion model, composed 1D magnetotelluric inversion models.

RESUMO. Este artigo apresenta um modelo geológico-geofísico ao longo do perfil NW-SE de 320 km na região central da bacia do Paraná, com base principalmente em um modelo de gravidade 2D que complementa as campanhas de campo magnetotelúricas (MT) realizadas pela Agência Nacional do Petróleo, Gás Natural e Biocombustíveis. Estudos de grandes estruturas dentro do porão embaixo de uma bacia sedimentar são de vital importância para a compreensão de sua evolução tectônica-estratigráfica. A bacia do Paraná possui um depocentro atingindo aproximadamente $7000 \mathrm{~m}$ de profundidade estimada. Duas grandes estruturas regionais são notáveis na área de estudo: 0 Arco Ponta Grossa e a anomalia NW-SE de alto valor de gravidade. A região também inclui grandes fluxos de lava representados pelas rochas basálticas da Formação Serra Geral. A intrusão de diques e soleiras de diabásio, que são principalmente ao Cretáceo, atingem igualmente a região. Um modelo regional foi criado por um processo de filtragem de comprimento de onda de $40 \mathrm{~km}$, usado para estimar a superfície do Moho. 0 valor de corte foi calculado considerando as fontes profundas do espectro de potência radial. 0 modelo gravimétrico final proposto inclui a topografia regional e apresenta um ajuste, com erro de 1.229 mGal. Sua parte mais rasa foi obtida através da análise de dados de seis poços estratigráficos e integrando uma seção composta magnetotelúrica 1D. As estruturas mais profundas do modelo foram conectadas a partir de estudos de refração sísmica profunda, análise de função de receptor e dispersão de ondas de superfície, em particular a profundidade de Moho de estudos prévios de sismologia e gravimetria por satélite. Os testes com modelos MT sintéticos suportam o modelo geológico-geofísico proposto, que apresenta algumas características notáveis: uma interface muito suave da interface crosta inferior - manto superior, que oscila em torno de $42 \mathrm{~km}$ de profundidade. A crosta superior foi representada por uma bacia sedimentar, e três blocos crustais, designados como Bloco Rio Paraná, Bloco Paranapanema e Bloco Apiaí, de acordo com o contexto geotectônico. 0 limite do embasamento da bacia, derivado dos modelos $1 \mathrm{D}$ MT, revelou uma superfície fraturada com uma profundidade média de $6000 \mathrm{~m}$. A porção sedimentar pode ser diferenciada em suas supersequências estabelecidas, mas não resolve os problemas causados por diques e soleiras.

Palavras-chave: espectro de potência médio radial, modelo de inversão gravimétrica, modelo composto de inversões 1D magnetotelúrico.

Observatório Nacional, Rua General José Cristino, 77, São Cristóvão, 20921-400 Rio de Janeiro, RJ, Brazil. Phone: +55(21) 3504-0140

- E-mails: victorcarreira@on.br; laterra@on.br; sergio@on.br 


\section{INTRODUCTION}

The Paraná sedimentary basin is located in south-central South America (Fig. 1), and it covers an area of approximately $1,100,000 \mathrm{~km}^{2}$, within the Brazilian territory. It also lies in the Republics of Paraguay, Uruguay, and Argentina, encompassing an area of $100,000 \mathrm{~km}^{2}$ (Zalán \& Wolf, 1987). Its evolutionary history began in the Cambrian age and is inserted in a context of marginal cratonic basins under a flexural crust domain (Borghi, 2002). It exhibits a depth of about 7000 meters at its depocenter and is filled with Paleozoic and Mesozoic sedimentary rocks. Lava flows formed the Cretaceous basaltic rocks, covering a great part of the basin surface, and reaches a thickness of 1700 meters. Intrusive rocks, which are also from the Cretaceous are present in the basin, marked by dikes and sills. The dikes form an outcrop belt bordering the basin in the Northeast, East, South, and West sections, covering much of the surface (Milani et al., 2007) apud (Borghi, 2002). The basin is bounded by the Alto Parnaiba Arch on the northeast border, the Ponta Grossa Arch on the eastern border, the Rio Grande Arch on the southern border, and links with the Assunção Arch on the northwest, originating the western border. The northwestern border is delimited by the São Vicente Arch (Zalán \& Wolf, 1987).

The basin exploration history is vast. Initial reports were raised dating from the XIX century in São Paulo. In the second half of the XX century, Schneider et al. (1974) proposed a stratigraphic revision of the Paraná Basin. Zalán \& Wolf (1987) subdivided the basin in five depositional sequences according to the subsidence cycles that are considered as supersequences by Milani et al. (2007). In the same period several geophysical surveys involving potential field data were carried out in the region, originating the first interpretations concerned with the evolution of the basement of the Paraná Basin. In particular, studies by Cordani et al. (1984), Quintas (1995), Vidotti et al. (1998), Hawkesworth et al. (2000) are notable. Works such as França \& Assumpção (2004), Lloyd et al. (2010), Assumpção et al. (2013), and Detzel et al. (2015) are important studies for understanding the crustal variation in Brazil. In the central region of the basin's study area, the electromagnetic and magnetic methods of Ussami et al. (1991), Menezes \& Travassos (2004), Bologna et al. (2013), and Padilha et al. (2015) are noteworthy.

This work was driven primarily towards proposing a density model that is in good agreement with the geology consecrated for the region. Other geophysical constraints were added to partly reduce the ambiguity generated when only one type of method is applied.

Two-dimensional direct modeling, linear, and non-linear inversion of gravity data along the $320 \mathrm{~km}$ long profile (Talwani et al., 1959; Talwani \& Heirtzler, 1960; Marquardt, 1963; Won \& Bevis, 1987) were used to delineate the subsurface geology, seeking to generate models with good fit between the observed and estimated data. In order to obtain a model that represents more reliably the geology of the subsurface, geophysical constraint data were used to create the final 2D model, including an $1 \mathrm{D}$ resistivity model derived from MT data and six stratigraphic wells A compilation of the Moho depth values based on seismological data (seismic studies of deep refraction, analysis of receptor function, and surface wave dispersion) was also used to constrain gravity modeling and interpretation (Assumpção et al., 2013).

The response test of the 1D Occam inversion methodology (Constable et al., 1987) to a complex basement, a synthetic resistivity model was proposed for a basin composed of horsts and graben structures.

The study area (Fig. 1) is located in the central portion of the Paraná sedimentary basin, between Mato Grosso do Sul, São Paulo, and Paraná States. The main data considered are data from a gravimetric aerial survey (National Petroleum Agency, year 2009-2010). The constraint data are log data from a set of six public wells from the MT land data survey acquired in 2014 by the National Petroleum Agency of Brazil.

\section{REGIONAL GEOLOGY AND GEOTECTONIC CONTEXT}

Paraná Basin was developed on a continental shield in the South Gondwana area and consists of a series of cratonic unities, surrounded by various mobile belts, and covered by molassic basins, which were developed during the thermo-tectonic Brasiliano cycle that extended from the Neoproterozoic to the Ordovician. The deformation resulting from this cycle lasted from $700 \mathrm{Ma}$ to $650 \mathrm{Ma}$, with most of the granite intrusion that we can observe in the basin within the boundary between the Proterozoic and Paleozoic (about $570 \mathrm{Ma}$ ), with a cooling period during the Cambro-Ordovician between 500-450 Ma (Zalán \& Wolf, 1987; Hawkesworth et al., 2000).

The basement that surrounds the Paraná basin is divided into the East/Southeast margin, characterized by the Dom Feliciano and Ribeira belts, Brasiliano age, and a NE-SW direction, and separated by a cratonic core named Rio de La Plata/Luiz Alves; the North/Northeast margin characterized by the Uruaçu belt, Mesoproterozoic age, and a NW direction, and two Archean blocks (Guaxupé and Goiás) remobilized during the Brasiliano cycle; the West/Northwest margin characterized by the fold belt Paraguay/Araguaia, which delimits the extreme northwestern basin border, and the Brasiliano time period (Hawkesworth et al., 2000; Borghi, 2002). 


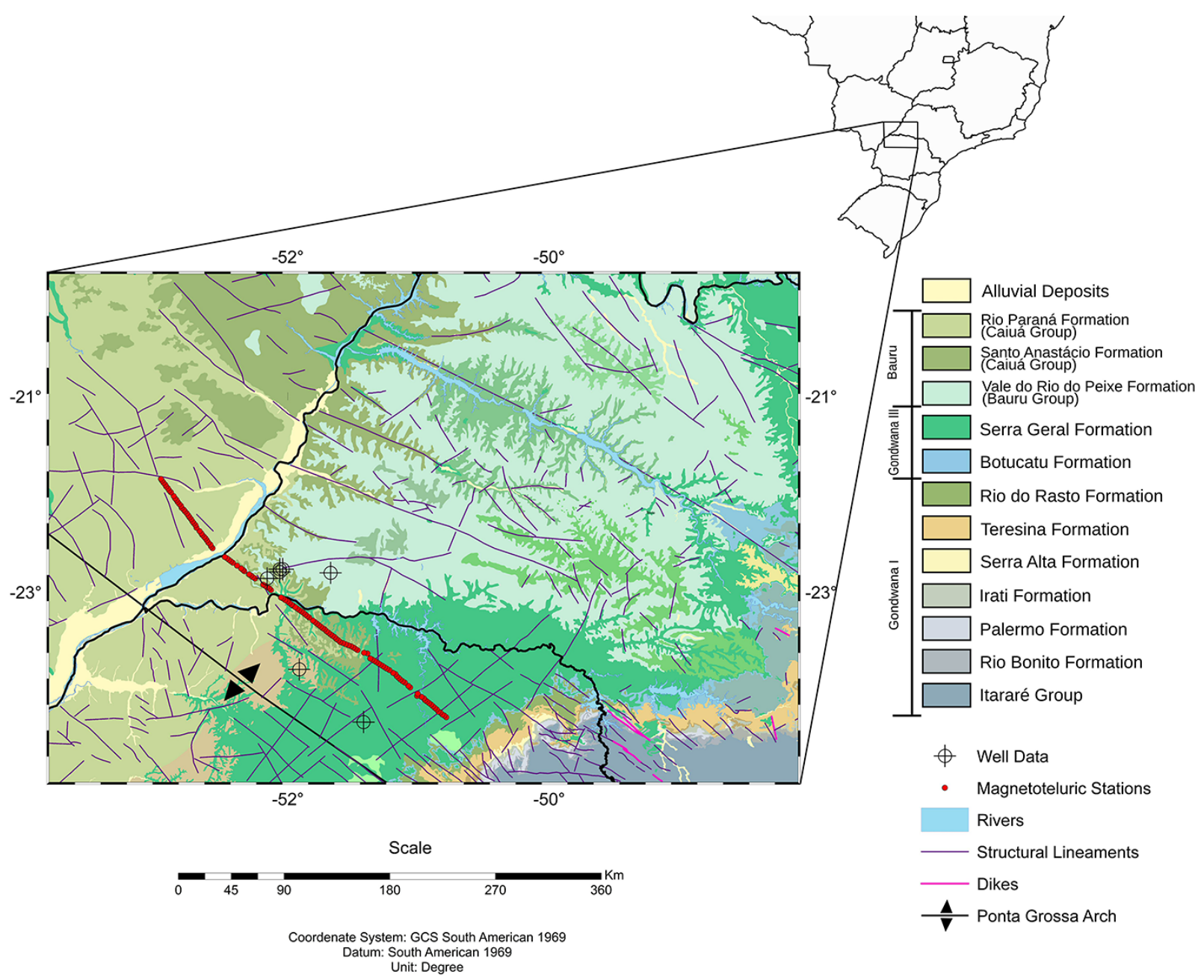

Figure 1 - This map represents the geology and the magnetotelluric profile location. Well data, main faults and the Ponta Grossa Arch are also represented.

Among the main structures groups, there are three lineament groups of preferential directions NW-SE, EW and NE-SW, each one representing a distinct thermo-tectonic event. The NW-SE lineament groups are the oldest and are related to the Transamazonic thermo-tectonic event, and geological faults zones associated with this event were reactivated during the South Atlantic rifting in the Cretaceous. The E-W lineaments started from the Triassic and are parallel to the oceanic fracture zones, suggesting a connection to the development of the South Atlantic. The NE-SW lineaments are derived from the Brasiliano thermo-tectonic event and its associated mobile belts. This latter set of lineaments is free of basalt dikes (Milani \& Zalán, 1999)

Stratigraphic record of Paraná Basin is formed by a sedimentary and magmatic package with a maximum thickness around $7,000 \mathrm{~m}$, which geographically coincides with the syneclise structural center and the channel of the Paraná River (Milani \& Ramos,
1998). The stratigraphic record of Paraná Basin is divided into six broad scale units or supersequences (Vail et al., 1977) as rocky packages with time intervals of a few tens of millions of years of duration and enveloped by surfaces of inter-regional character of unconformity: Rio Ivaí (Ordovician-Silurian), Paraná (Devonian), Gondwana I (Carboniferous-Eotriassic), Gondwana II (Meso to Neotriassic), Gondwana III (Neojurassic-Eocretaceous) and Bauru (Neocretaceous). The first three supersequences are represented by sedimentary sequences that define transgressive and regressive cycles linked to fluctuations in relative sea level during the Paleozoic, while the rest correspond to continental sediment packages with associated igneous rocks. The formal lithostratigraphy units, whichever are the groups, formations and members commonly used in describing the spatial arrangement of the basin strata, are inserted as individualized elements in the regional scale aloestratigraphic framework (Milani et al., 2007). 
The structural-geological map (Fig. 1) presents the outcropping formation as well as main lineaments and the Ponta Grossa Arch (Bizzi et al., 2003). For the basement part an adaptation from Milani \& Zalán (1999) was used in attempted to model the section (Fig. 2).

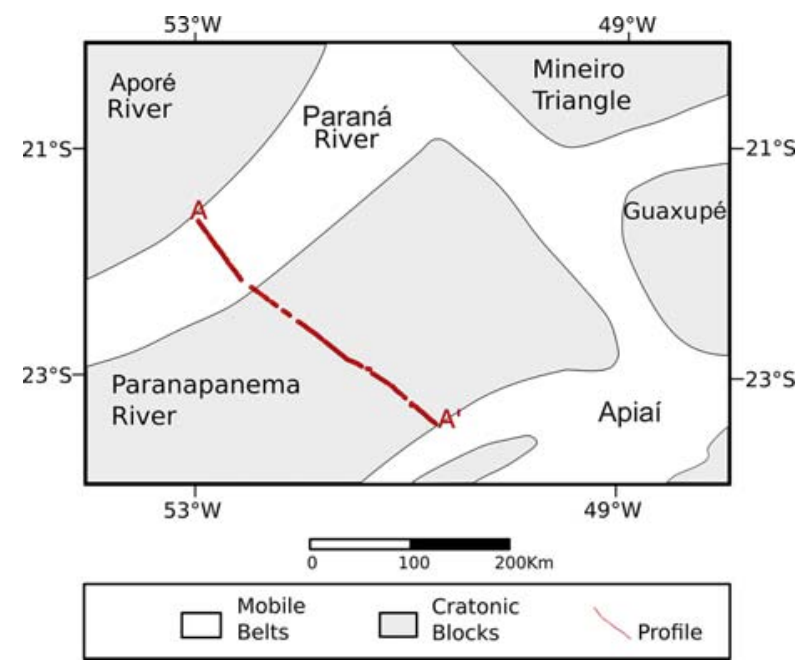

Figure 2 - Tectonic context of Paraná Sedimentary Basin. The red line is the MT profile and the white and grey blocks are the mobile belts and cratonic blocks respectively (Milani \& Zalán, 1999).

\section{METHODOLOGY}

Bouguer anomaly data contain overlapping anomalies of various causative sources with shallow, middle, and deep origins. Smooth anomalies of a wide lateral extent or of a large wavelength are due to regional geological features associated with the deep structures and are called regional anomalies.

In regional studies, it is good practice to remove the anomalies of small lateral extensions, thus enhancing large structures. They are important for understanding the geological structures deep inside the planet, especially the crust and mantle interface called Moho (Beltrão et al., 1991).

This work distinguishes the deep causative sources based on the calculation of the radial power spectrum average associated with the wavelength filter. According to Spector \& Grant (1970) Fourier analysis is an important tool for interpreting gravity field data. Spector \& Bhattacharyya (1966) and Spector (1968) highlighted important concepts in the application of statistical models and ensemble averaging.

For the $2 \mathrm{D}$ gravity modeling section of the lower crust/upper mantle interface, it was necessary to remove the shorter wavelengths from the total Bouguer anomaly data, yielding the regional field result. In this approach, a Fourier Transformation is used to change from the spatial to the frequency domain, in geodesic coordinates. Logarithmic spectra were calculated to add all the parameters of depth values. The linear regression was applied to a set data the deep part. The result was used to constrain the wavelength cutoff parameter. This information was considered as the regional field of the studied profile associated with deep geological structures such as the Moho.

Crustal thickness parameters from previous studies, such as Assumpção et al. (2013), corroborate the Moho average depth calculated from the regional model.

The non-uniqueness of geophysical models has been welldocumented in literature for several years (Backus, 1970; Jackson, 1979) and, therefore, it is important to search for ways to overcome their limitations and diminish possible ambiguities. One such way is to provide a priori information by different geophysical methods and well log data, seeking to reduce uncertainties.

Aerogravimetric data was integrated in results from geophysical models, which derive MT and well log data, and have been included in the gravity modeling. This approach is useful in the study of crustal blocks by combining contrasts of distinct physical properties such as density and electrical resistivity (Telford et al., 1998).

The final gravimetric model takes into account the topography and was applied in the following procedures: a) the limits of the Moho structures, added to the bibliography data (Assumpção et al., 2013), were modeled from the regional Bouguer anomaly data; b) the shallow geological structures, based on the composed section of the 1D MT inversion models for the basement limit, the geologic literature; and data from the logging wells were used as initial data to limit some stratigraphic supergroups. All data was adjusted from the total Bouguer anomaly, as the Moho model was already fixed.

A hypothetical test using 1D MT composed section to define the basement limit is a new methodology presented in this work. Synthetic data simulates the behavior of a syneclise basin limited by geological structures, such as horst and grabens, underlying a high resistivity basement. The sedimentary rocks have a low resistivity if compared to the basement portion and are considered to have a $1 \mathrm{D}$ reality counteracting the 2D/3D basement portion. This contrast allows the differentiation of a new interface, designated as a basin-basement limit interface. The main crustal blocks of the basin-basement limit interface is fixed, and there are lateral extensions and depths that were created as a result of tectonic activity and density inversion of the calculated total Bouguer anomaly curve. 

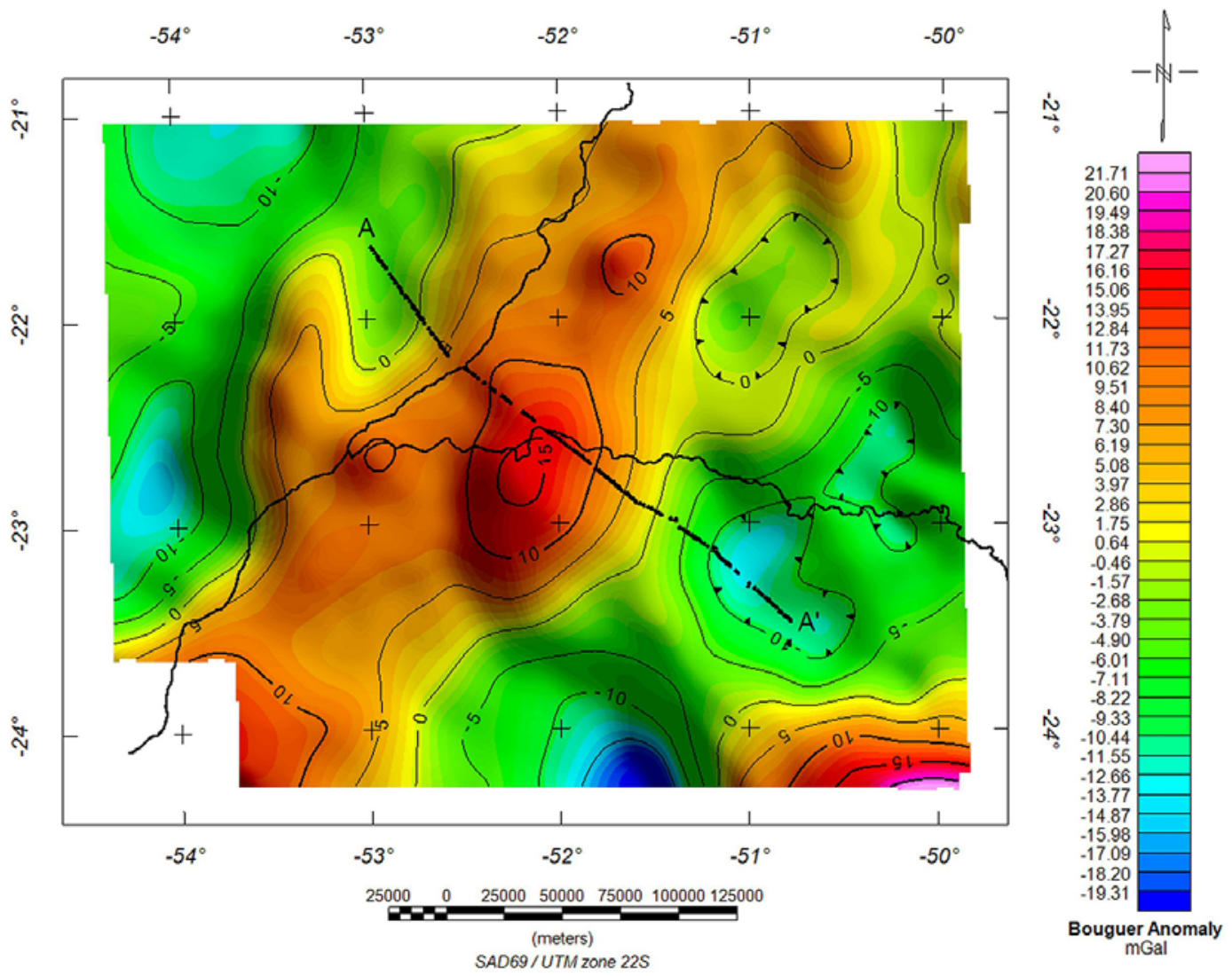

Figure 3 - Bouguer anomaly map and MT-profile.

\section{Gravimetric Data}

The modeled section region has an aerogravity coverage data acquired at a height of 1800 meters with a regular grid produced by $6 \mathrm{~km}$ north and south flight lines. The control lines are equidistant by $18 \mathrm{~km}$.

The Earth's gravitational field variation corrections, not arising from changes in the rock density, known as gravimetric reduction, were performed on data before the modeling and inversion phases. The equipotential surface of the geoid, which coincides with the average level of the undisturbed sea, was utilized as the reference level. In gravity reduction, the tidal effect is removed from the observed gravity data, minimizing the lunisolar attraction and static drift effects. The instrumental drift caused by the distention of the gravimeter spring was always corrected with the closure on a 1st order of the Brazilian Fundamental Gravity Network (RGFB) gravimetric base (Longman, 1959; Mota, 2008).

The latitude correction was based on the International Gravity Formula 1967. The Eötvös and Terrain corrections were also conducted (Kane, 1962; Nagy, 1966; Telford et al., 1998). The gravity value compensation, due to the altitude of the measurement relative to the datum, was made from the free-air correction.
The mass effect correction was carried out in the complete Bouguer reduction, using the gravity curvature (Bullard B) correction (Heiskanen \& Moritz, 1965; La Fehr, 1991).

The total Bouguer anomaly map was created by a bidirectional interpolation of the observed gravity data after the corrections. The grid data was sampled in a straight section, $320 \mathrm{~km}$ long, coincident with the magnetotelluric profile (Fig. 3).

\section{Regional Separation}

The large wavelength anomalies are associated with the deep anomalies, of regional character (Telford et al., 1998).

According to this hypothesis, the total gravimetric anomaly data is assumed to consist of the superposition of a large number of individual anomalies, most of them overlapping, which are caused by several ensembles of blocks having various dimensions and densities. Fourier analysis is an important tool for interpretation gravity field data. Spector \& Bhattacharyya (1966) and Spector (1968) demonstrated important concepts in the application of statistical models and ensemble averaging.

An important postulate states that the mathematical expecta- 
tion of the value of the power density function is equal to the ensemble average of $E$ (Spector \& Grant, 1970). Analysis of the Bouguer anomaly data in the frequency domain shows that it is possible to define the total ensemble as in Eq. (1)

$$
E_{\text {total }}=E_{d}+E_{m}+E_{s},
$$

where the total logarithmic ensemble is in the frequency domain, $E_{\text {total }}$, adding the tree minor ensembles originating from deep $\left(E_{d}\right)$, middle $\left(E_{m}\right)$ and shallow sources $\left(E_{s}\right)$. Figure 4 shows the power spectrum data of the study area and highlights the ensemble of the data for the deep sources. Linear regression was applied to this dataset to calculate the depth of the source.

The calculated value of the deep ensemble data from $40 \mathrm{~km}$ was used to constrain the wavelength cutoff parameter and used in the determination of the upward continuation filter, Eq. (2),

$$
\beta_{(\omega)}=\frac{Z_{x x(\omega)}-Z_{y y(\omega)}}{Z_{x y(\omega)}+Z_{y x(\omega)}}
$$

where $k$ is the wavenumber frequency domain and $h$ is the distance in kilometers.

The result shows the filtered regional field maps and profile data sampled (Fig. 5), associated with the deep Moho geological structures.

\section{Geophysical Data Constraints}

To validate the value of the density of the studied sedimentary rocks, density data from six well logs located in the region of the Paraná Basin close to the selected profile were used in gravity modeling.

A set of 150 broadband MT stations spaced every $2 \mathrm{~km}$ on the same profile were used in gravity modeling to outline the basin's basement top.

\section{Well Data}

Data from the average density were compiled from the analysis of six wells localized around the study area. The geologic formations were divided into supersequences, formations, and depositional groups (Vail et al., 1977; Milani \& Ramos, 1998; Milani \& Zalán, 1999). The density references values for the basement and upper mantle, based on geophysical literature, were also added to this table (Quintas, 1995; Telford et al., 1998; Quintas et al., 1999). Figure 6 presents a lateral correlation between six wells among the gravity section.

The densities values of the sedimentary blocks units were calculated from the six well shown on Figure 6. For each supersequence an average density were calculated. From the youngest cycle of sedimentation to the oldest the values of densities used were: $2200 \mathrm{~kg} / \mathrm{m}^{3}$ (Caiuá Group), $2817 \mathrm{~kg} / \mathrm{m}^{3}$ (Serra Geral Formation), $2388 \mathrm{~kg} / \mathrm{m}^{3}$ (Botucatu Formation), $2597 \mathrm{~kg} / \mathrm{m}^{3}$ (Gondwana I), $2449 \mathrm{~kg} / \mathrm{m}^{3}$ (Paraná) and $2656 \mathrm{~kg} / \mathrm{m}^{3}$ (Ivaí River).

\section{Synthetic Resistivity MT Model}

The magnetotelluric method is a non-invasive method capable of estimating the contrast in resistivity in the sub-surface from measurements on the surface of the natural magnetic and electric fields. In the MT method, elements of the impedance tensor are calculated in the frequency domain $Z(\omega)$ between the incident and induced electric and magnetic horizontal field components, which are given by a $2 \times 2$ matrix of the complex impedance tensor Eq. (3) (Jones, 1988).

$$
E(\omega)=Z(\omega) H(\omega) .
$$

Equation (4) shows the tensor in matrix format,:

$$
\left[\begin{array}{l}
E_{x}(\omega) \\
E_{y}(\omega)
\end{array}\right]=\left[\begin{array}{ll}
Z_{x x(\omega)} & Z_{x y(\omega)} \\
Z_{y x(\omega)} & Z_{y y(\omega)}
\end{array}\right] \cdot\left[\begin{array}{l}
H_{x}(\omega) \\
H_{y}(\omega)
\end{array}\right] .
$$

The apparent resistivity $\rho$ and the phase $\phi$ are obtained from impedance tensor $Z(\omega)$, from Eqs. (5) and (6), respectively (Vozoff, 1991).

$$
\begin{aligned}
& \rho_{a, i j}=\frac{1}{\rho \mu_{0}}\left|Z_{i j(\omega)}\right|^{2}, \\
& \phi_{i j}=\tan ^{-1}\left(\frac{I\left(Z_{i j(\omega)}\right)}{R\left(Z_{i j(\omega)}\right)}\right) .
\end{aligned}
$$

For modeling the basement top with MT data, a layered 1D resistivity model was generated to correlate to the horizontal stratigraphic behavior of the Paraná basin.

The hypothesis test that discretizes the basement relief was conducted through direct and inverse modeling of 1D MT data. The bidimensional section represents a sedimentary basin like the study area. A discretized cell mesh with different resistivity values representing the geophysical section was prepared from the hypothetical geological model. The geophysical model (Fig. 5) is composed of two layers representing the basin sedimentary rocks, which were assigned different resistivity values, from 10 to $341 \Omega . m$. Values higher than $341 \Omega$.m was assigned for the basement. A rough relief representing the basement surface was created by simulating horst and graben geological structures. A set of 22 stations with 5-km spacing was distributed along the section. Synthetic curves of resistivity and phase were generated by the $2 \mathrm{D}$ algorithm on the proposed geophysical model (Rodi \& 


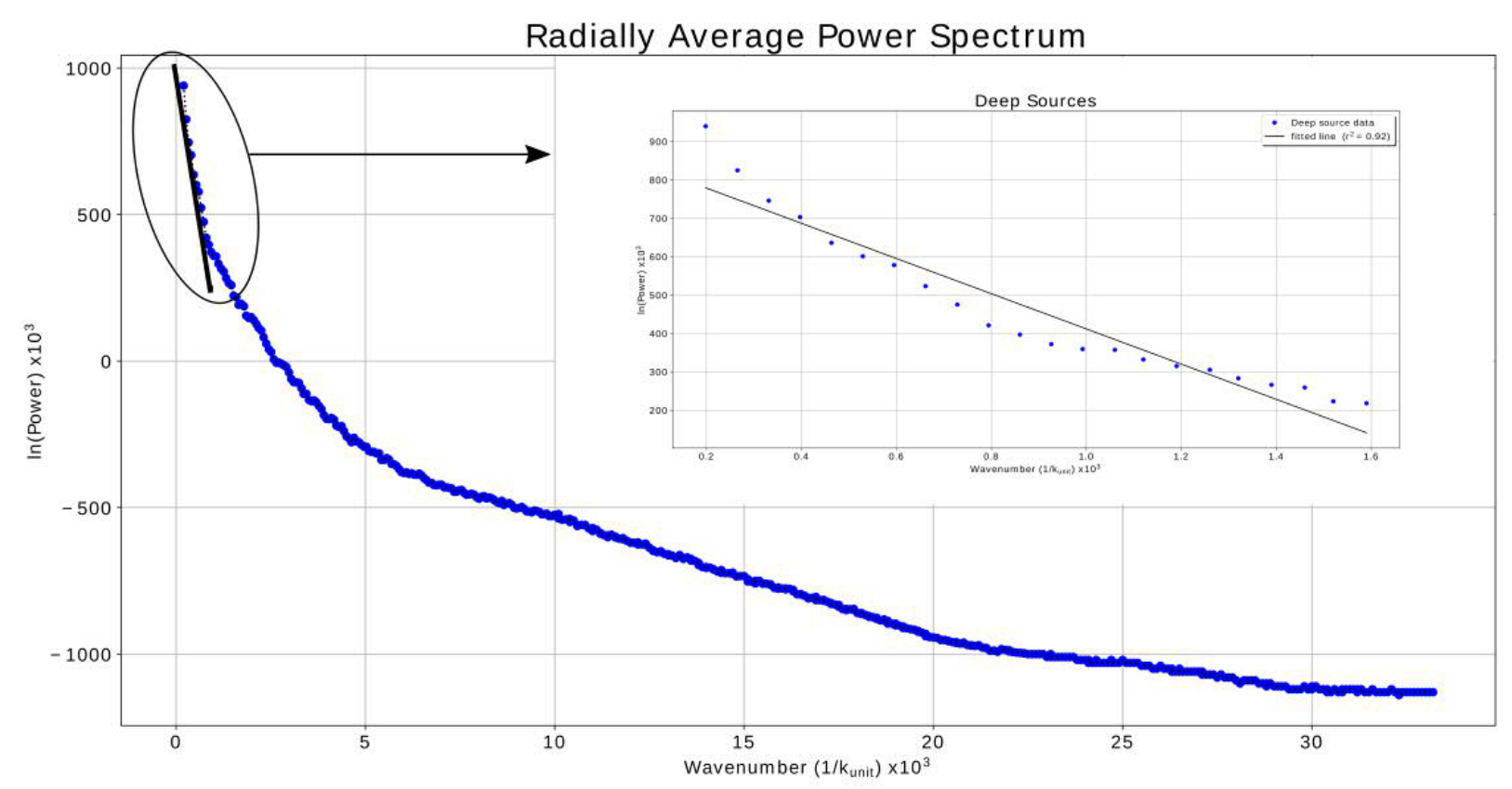

Figure 4 - Radially average power spectrum for the total data. The zoom box presents the ensemble of the highest values of frequence.

Mackie, 2001). A 2.5\% Gaussian random noise level was added to the synthetic data (Fig. 7).

One-dimensional behavior is considered in synthetic data when the resistivity apparent curves in directions $X Y$ and $Y X$ overlap, hence no lateral variations in resistivity. The portion of data that did not present $1 \mathrm{D}$ reality was discarded - for example, 2D and 3D (Simpson \& Bahr, 2005) that represents the boundary of the basement and sedimentary basin. An example is shown in Figure 8 of the MT22 station.

The resistivity synthetic data from MT22 stations was inverted by the 1D Occam algorithm from Constable et al. (1987). The $1 \mathrm{D}$ Occam code smoothens large contrasts of resistivity through many small layers. This can be used to start the simulation of the layered models. Figure 9 shows the results of $1 \mathrm{D}$ inversion of the MT22 station. The left panel shows only the adjustment to the representative data of the basin. The basement part was discarded, as previously explained. The right panel shows the 1D Occam inversion results. The crosshatch represents the layered model.

Figure 10 shows the comparative results of the $1 \mathrm{D}$ synthetic MT section with the surface delimiting the basement. The vertical columns represent the results of the $1 \mathrm{D}$ inversion of the layered models. In the layered models the lighter color represents the basin and the darker represents the basement. The inversion results show good correlation with the basin-basement, although the MT1, MT21, and MT22 stations localized in the eastern and the western borders presented errors in the basement depth on the order of 500 meters.

This imprecision in the depth values after $1 \mathrm{D}$ inversion is associated with the Gaussian random data noises that were inserted in the synthetic data, and that same behavior is noted on the real data due to the natural noise and ambiguities of gravimetric data.

The methodology proposed for the basement surface discretization using modeling and $1 \mathrm{D}$ inversion was able to define an approximate surface of high resistivity contrast between the sediment and basement.

\section{Real Data Resistivity MT Model}

We use a set 150 broadband magnetotelluric stations acquired at the scope project ANP/ON 2013 (National Agency of Petroleum, Natural Gas and Biofuels - Brazil). The $1.8 \mathrm{~km}$ spacing between the stations were used to the $320 \mathrm{~km}$ study profile. The MT data were processed applying a robust technique (Egbert \& Booker, 1986) and remote reference (Gamble et al., 1979). The robust processing scheme is based on multivariate statistical methods. This approach improves signal-to-noise ratios and eliminates coherent noise. The processing cleans up outliers in the resistivity data. Coherent time-series segments from each frequency band were selected automatically for robust analysis to reduce the effects of bias because of noise. An iterative re-weighting scheme was used to provide a robust estimate of the impedance 


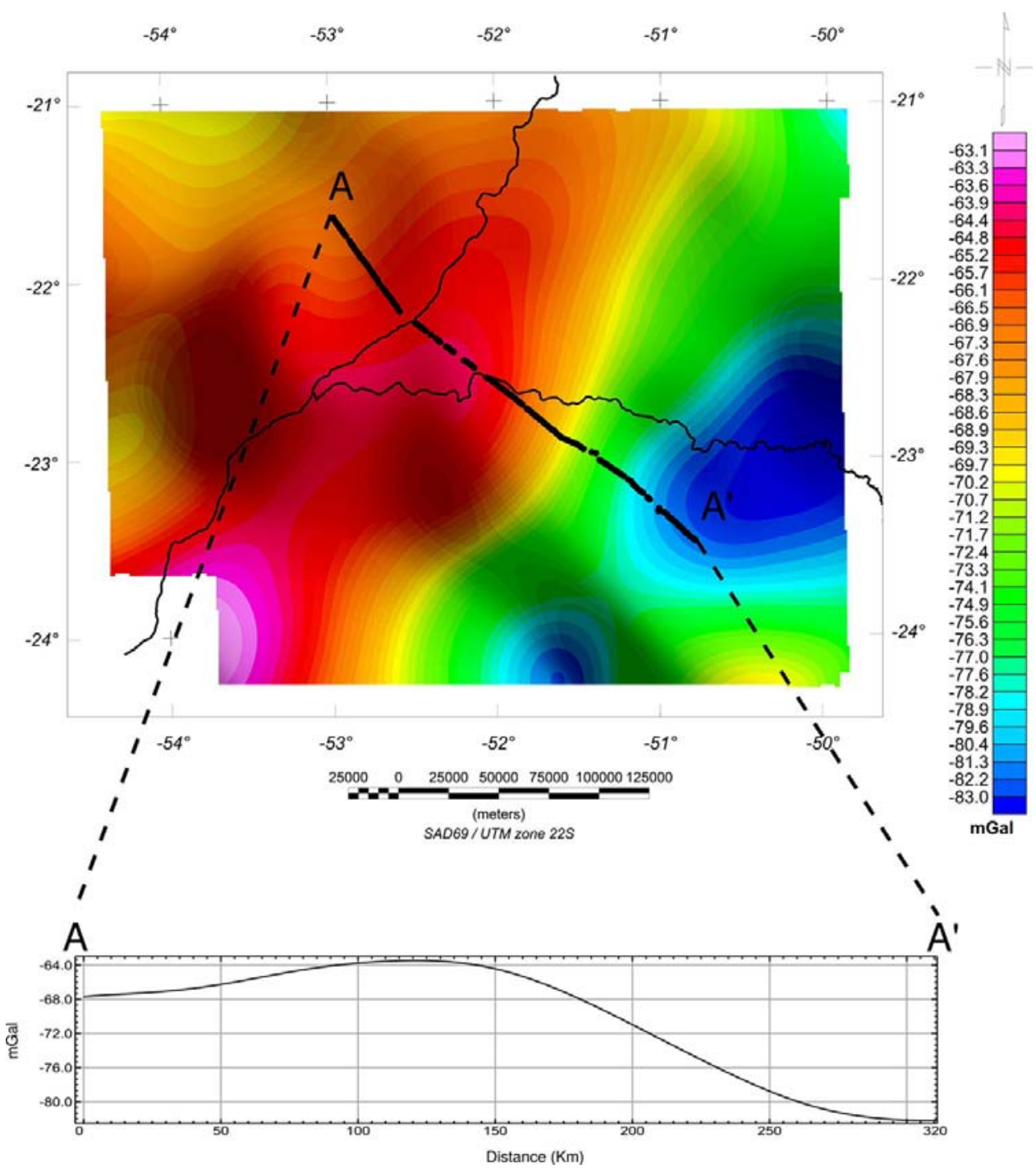

Figure 5 - Bouguer anomaly map of a $40 \mathrm{~km}$ upward continuation cutoff. And above the dotted line the A-A' sample profile.

tensor and the associated apparent resistivity and phase curves (Egbert \& Booker, 1986).

A static shift (SS) correction of the apparent resistivity curves with use of the TEM (Transient Electromagnetic) (Gamble et al., 1979; Meju, 1994; Árnason, 2008) resistivity curves was necessary to remove the galvanic distortion caused by heterogeneities or 3D shallow-surfaced bodies (Sternberg et al., 1988; Árnason, 2008; Mwakirani et al., 2012).

Figure 11 shows the displacement of the SS factor for the ON-252 station on the apparent resistivity curve in comparison to TEM data.

For a 1D Earth, conductivity varies only with depth. In the case of a 2D Earth, conductivity variation occurs along one of the horizontal directions and along the vertical. The $1 \mathrm{D}$ and $2 \mathrm{D}$ cases assume the following values (Simpson \& Bahr, 2005; Figueiredo, 2008), respectively (Eq. 7),

$$
\overbrace{\begin{array}{c}
Z_{x x(\omega)}=Z_{y y(\omega)}=0 \\
Z_{x y(\omega)}=-Z_{y x(\omega)}
\end{array}}^{1 D} \overbrace{\begin{array}{c}
Z_{x x(\omega)}=-Z_{y y(\omega)}=0 \\
Z_{x y(\omega)} \neq-Z_{y x(\omega)}
\end{array} .}^{2 D} .
$$

On the other hand, the invariants are all non-zero for the 3D case (Figueiredo, 2008).

Simple classic parameters, such as the Tipper function and the ellipticity, were utilized for the dimensionality analysis. The ellipticity varies according to the amplitude and direction of the impedance tensor components and can be expressed as in Eq. (6) 


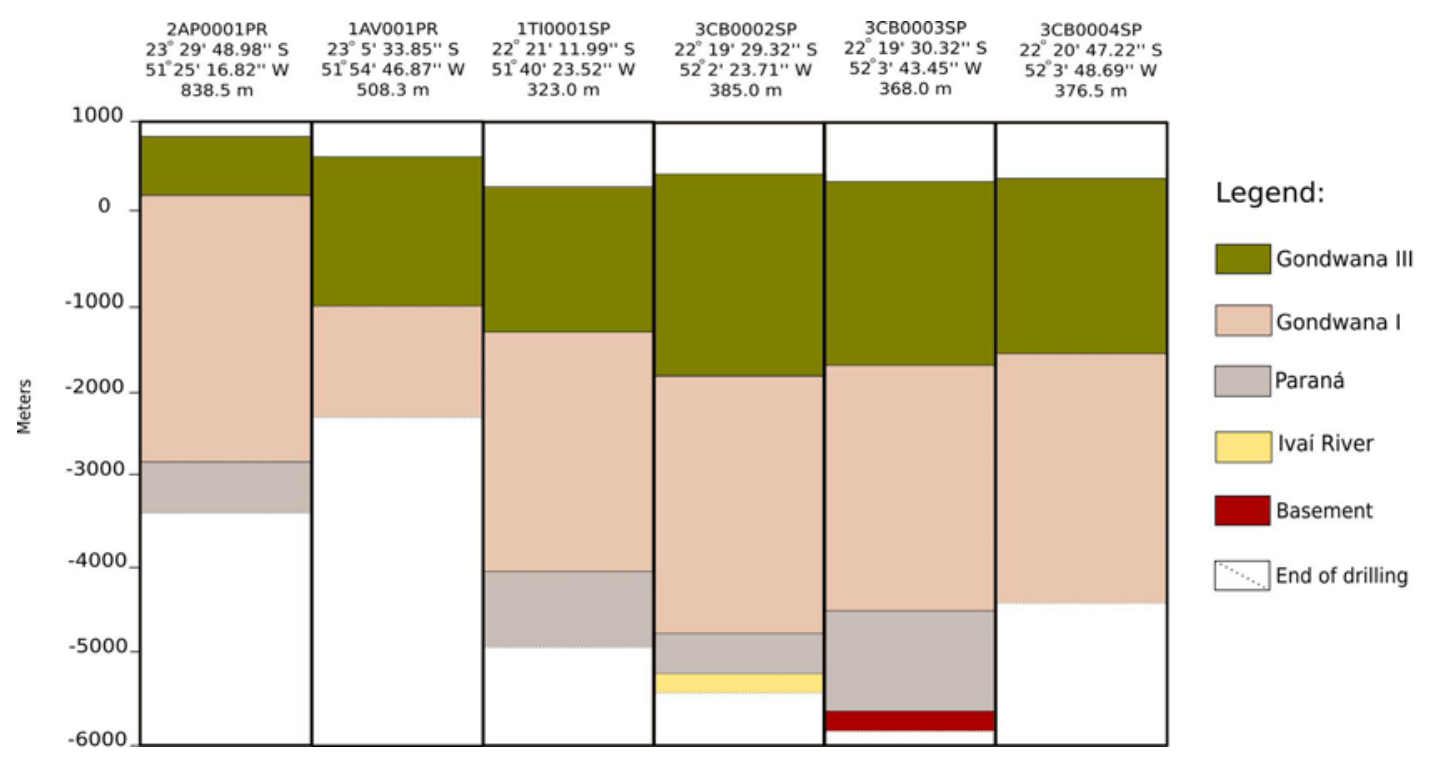

Figure 6 - Lateral correlation among six wells inside sedimentary basin domain. Figure upper part is public wells code name, geographic coordinates and altimetry. Legend shows the sediment geological units and the depth limits for each well.

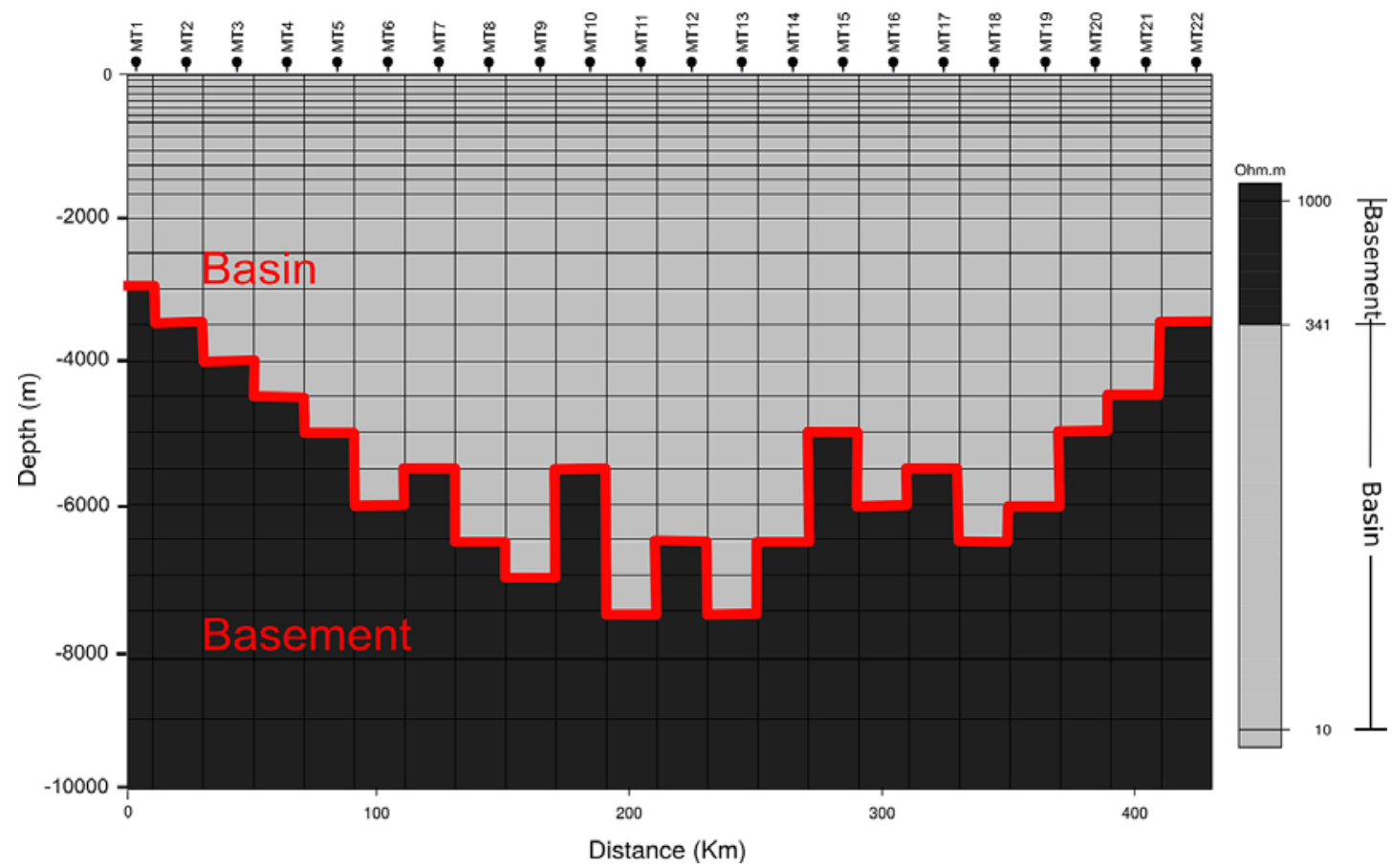

Figure 7 - The hypothetical 2D Earth. The red line marks the limit between the sedimentar basin and the basement.

(Vozoff, 1991; Simpson \& Bahr, 2005).

$$
\beta_{(\omega)}=\frac{Z_{x x(\omega)}-Z_{y y(\omega)}}{Z_{x y(\omega)}+Z_{y x(\omega)}} .
$$

The $Z_{x x(\omega)}-Z_{y y(\omega)}$ and $Z_{x y(\omega)}+Z_{y x(\omega)}$ terms are invariant constants of the impedance tensor (Figueiredo, 2008).
In a $1 \mathrm{D}$ situation, this property is zero for a noise free dataset (Vozoff, 1991). Figure 12 illustrates the analysis of the ellipticity of $0 \mathrm{~N}-252$ station.

When there is no lateral variation, $H_{z}$ is considered to be approximately zero (Vozoff, 1991; Simpson \& Bahr, 2005). For any frequency, the $H_{z}$ and the horizontal magnetic field relation can 


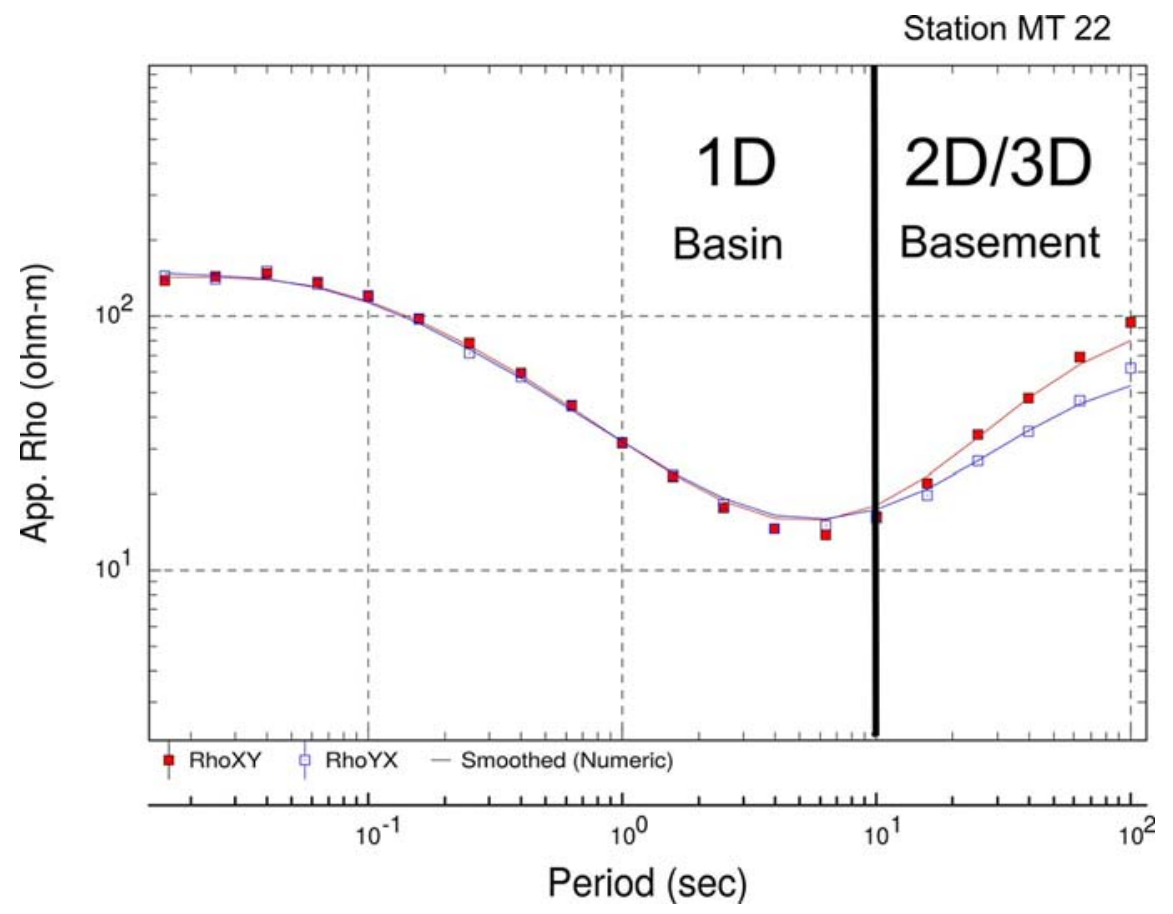

Figure 8 - Dimensional analysis for station MT22.

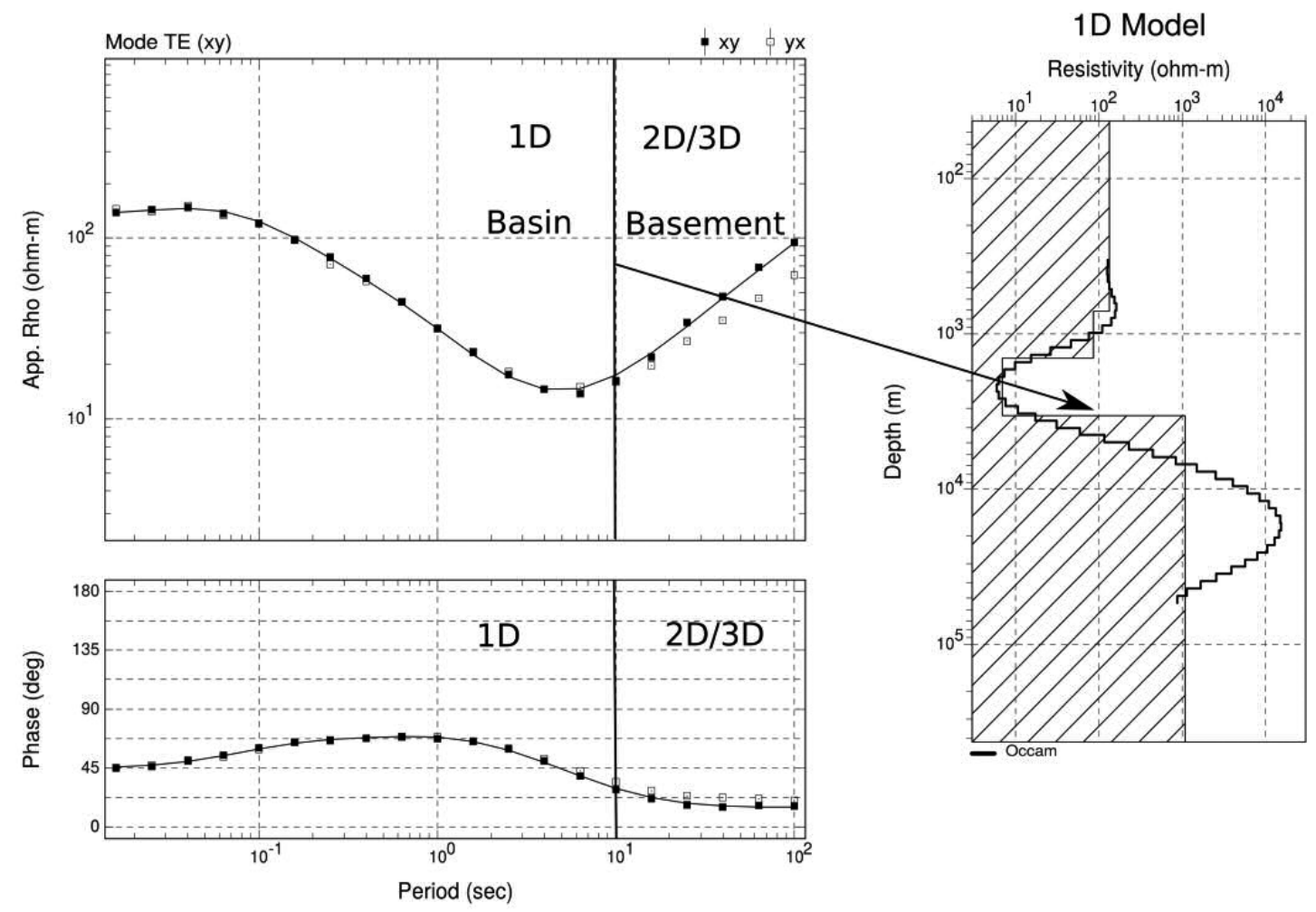

Figure 9 - Synthetic inversion for station MT22. 


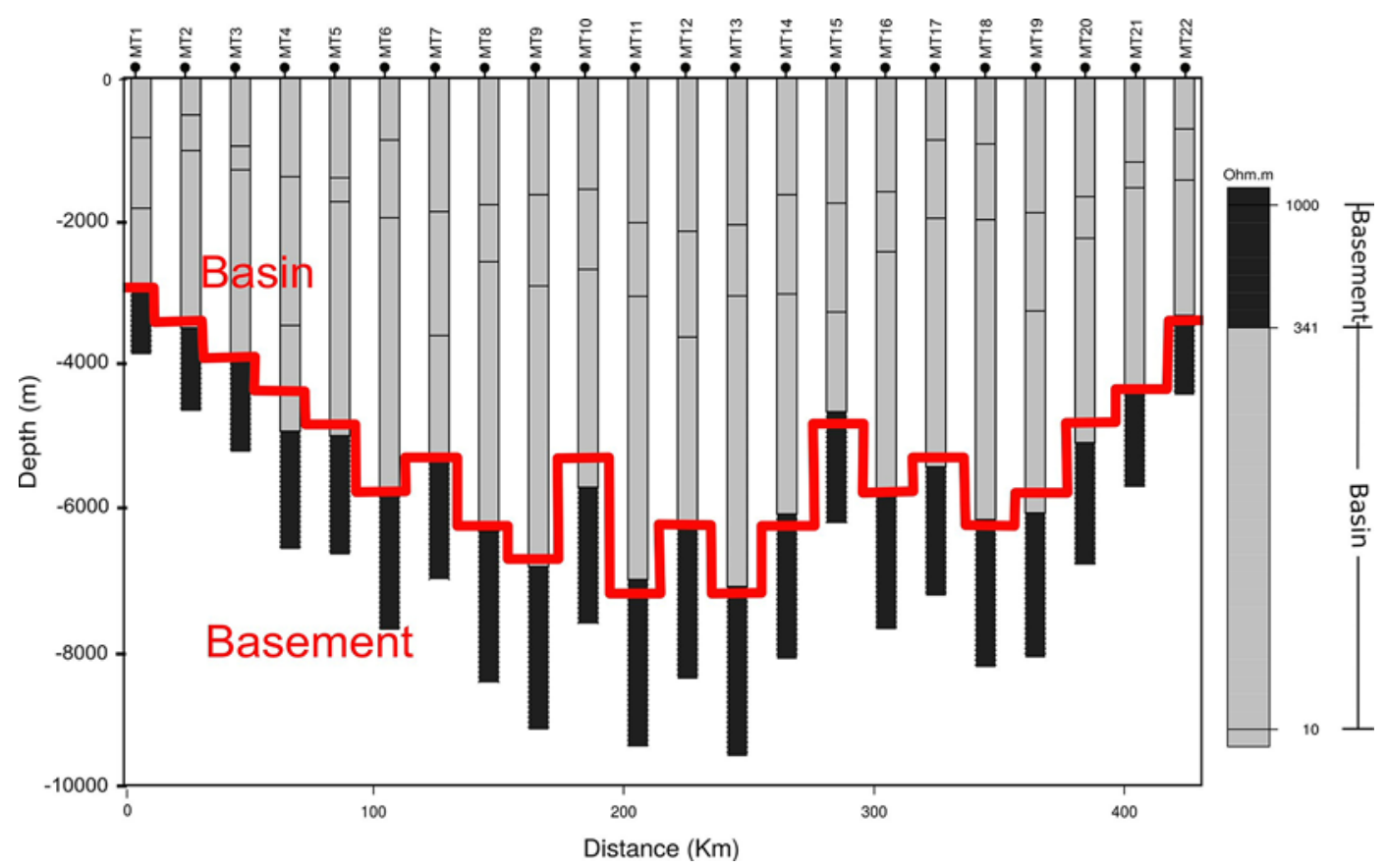

Figure 10 - Composed $1 \mathrm{D}$ profile. The red line shows the original basement.
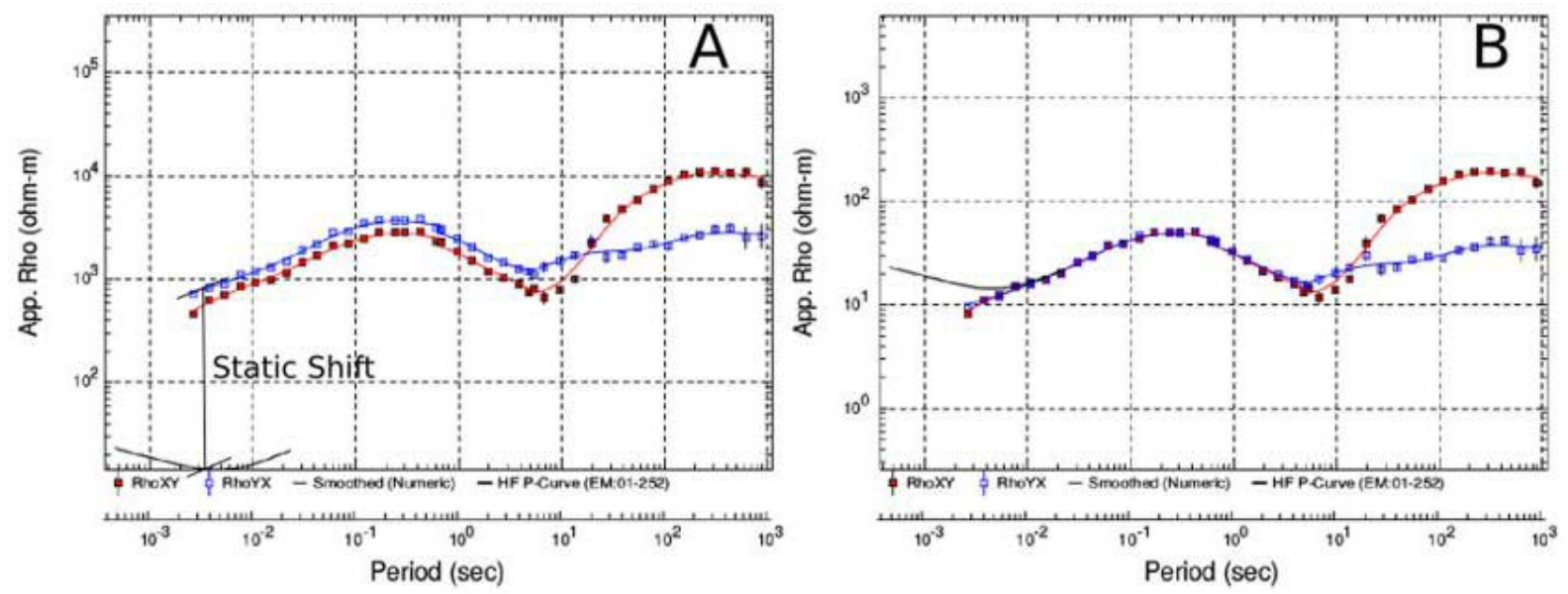

Figure 11 - SS correction for station ON252. The black line represents TEM resistivity. In (A) MT resistivity result with static shift. In (B) the resistivity result corrected. The black line shows the displacement of resistivity values.

be written as in Eq. (9).

$$
H_{z}=T_{x} H_{x}+T_{y} H_{y} .
$$

As in a 2D Earth with strikes in the $X$ direction, Eq. (9) can be rewritten as Eq. (10),

$$
H_{z}=T_{y} H_{y},
$$

where $T^{\prime}$ is the inclination of vector $H$, related to the horizontal plane, also called the Tipper function. The value of the Tipper function is equal to zero for a noise free dataset for a $1 \mathrm{D}$ case (Vozoff, 1991).

For this study, the Tipper function values close to zero were selected as being from a $1 \mathrm{D}$ Earth (basin) because the real data is never noise free. The dimensionality change for $2 \mathrm{D}$ or $3 \mathrm{D}$ happen on the break of the Tipper curve (basement), as shown in Figure 10. The unidimensional behavior of the MT curve is identified when the components $X Y$ and $Y X$ (apparent resistivity and phase curves) are equal. 


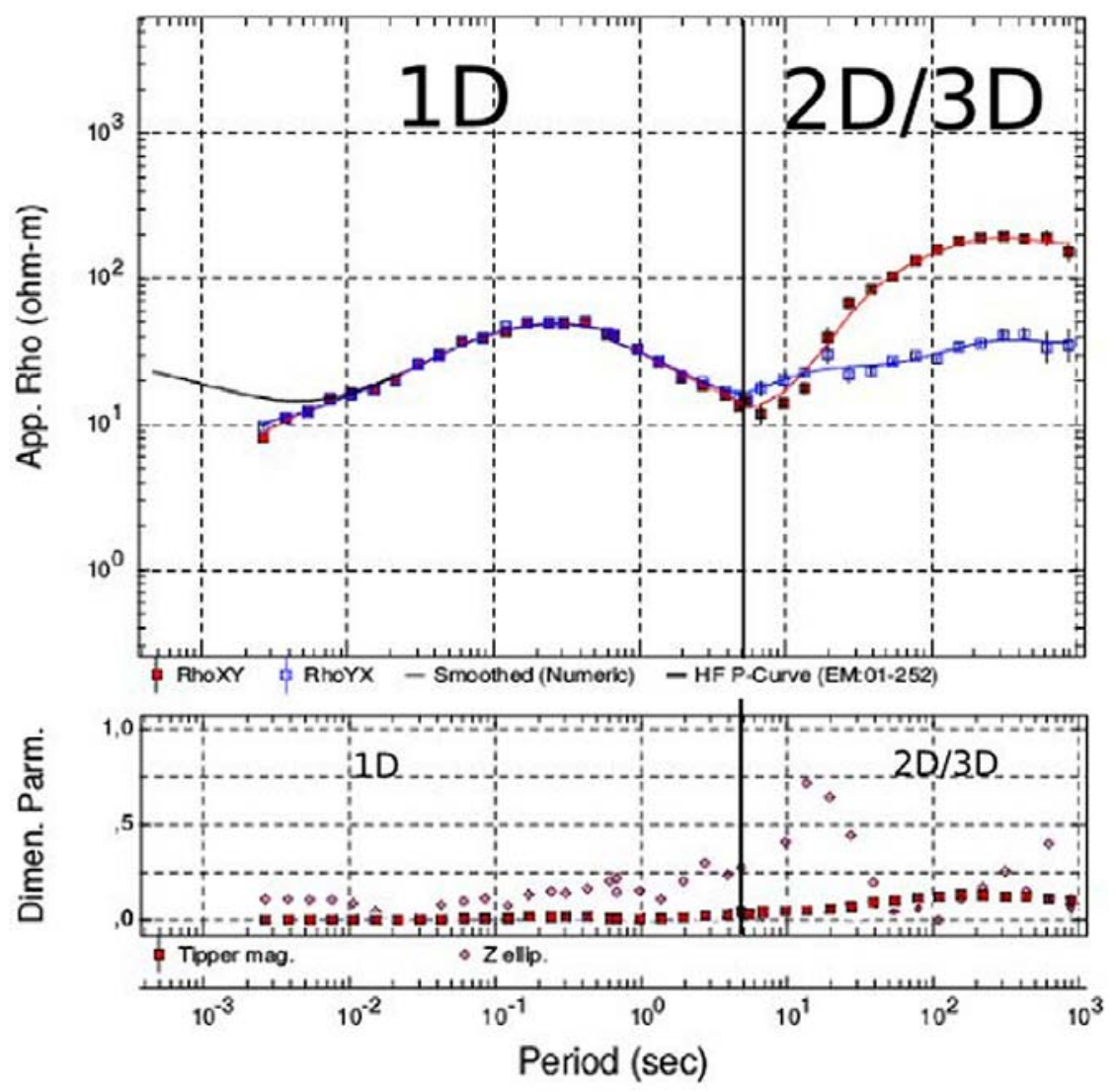

Figure 12 - Dimensionality analysis for a real data station.

The MT results suggested appreciable variation in the dimensionality of the studied area, but it is predominantly $1 \mathrm{D}$ for the higher frequencies, which are related to depths within the basin formations. The same methodology applied to the synthetic data was extended to the real data (1D cut and 1D 0ccam inversion) as displayed in Figure 12 (Constable et al., 1987).

The basement depth was determined with the production of the 1D composed MT section, based on the resistivity contrast between basement and sedimentary basin. Figure 13 shows the final results of the $1 \mathrm{D}$ MT inversions with real data.

\section{RESULTS}

\section{D Gravity Model}

Process of modeling the gravimetric data added to other geophysical data was performed iteratively, allowing the adjustment of the estimated data to the observed ones with the smallest possible error (La Terra et al., 2015). The methods used to determine the response of the models are based on Talwani et al. (1959) and Talwani \& Heirtzler (1960), using the algorithms described in Won \& Bevis (1987).
The model reveals how density varies in the subsurface along the section. The geological structures were simplified using linear structures. These features were approximated by a set of $n$-vertices polygons. It was possible to calculate the vertical component of the gravitational attraction at any point by varying the position of the $n$-vertices, the polygons, and densities (Talwani et al., 1959).

The $320 \mathrm{~km}$ NW-SE profile, A-A', was sampled over the magnetotelluric section from a Bouguer anomaly map that intersects a gravimetric high (Fig. 3).

Geological information, multidisciplinary geophysical model interpretation, and compiled Moho data were used as an initial reference for the modeling with the main objective of reducing the solution's ambiguities and validating the gravity data adjustment with the idealized geologic model.

The 2D gravimetric modeling was executed to adjust the Bouguer anomaly data by BDEP/ANP (Exploration and Production Database - National Agency of Petroleum, Natural Gas and Biofuels - Brazil). A geometric mass distribution in the subsurface was simulated from geological well data, seismology, and the $1 \mathrm{D}$ MT section information through density contrast. This 


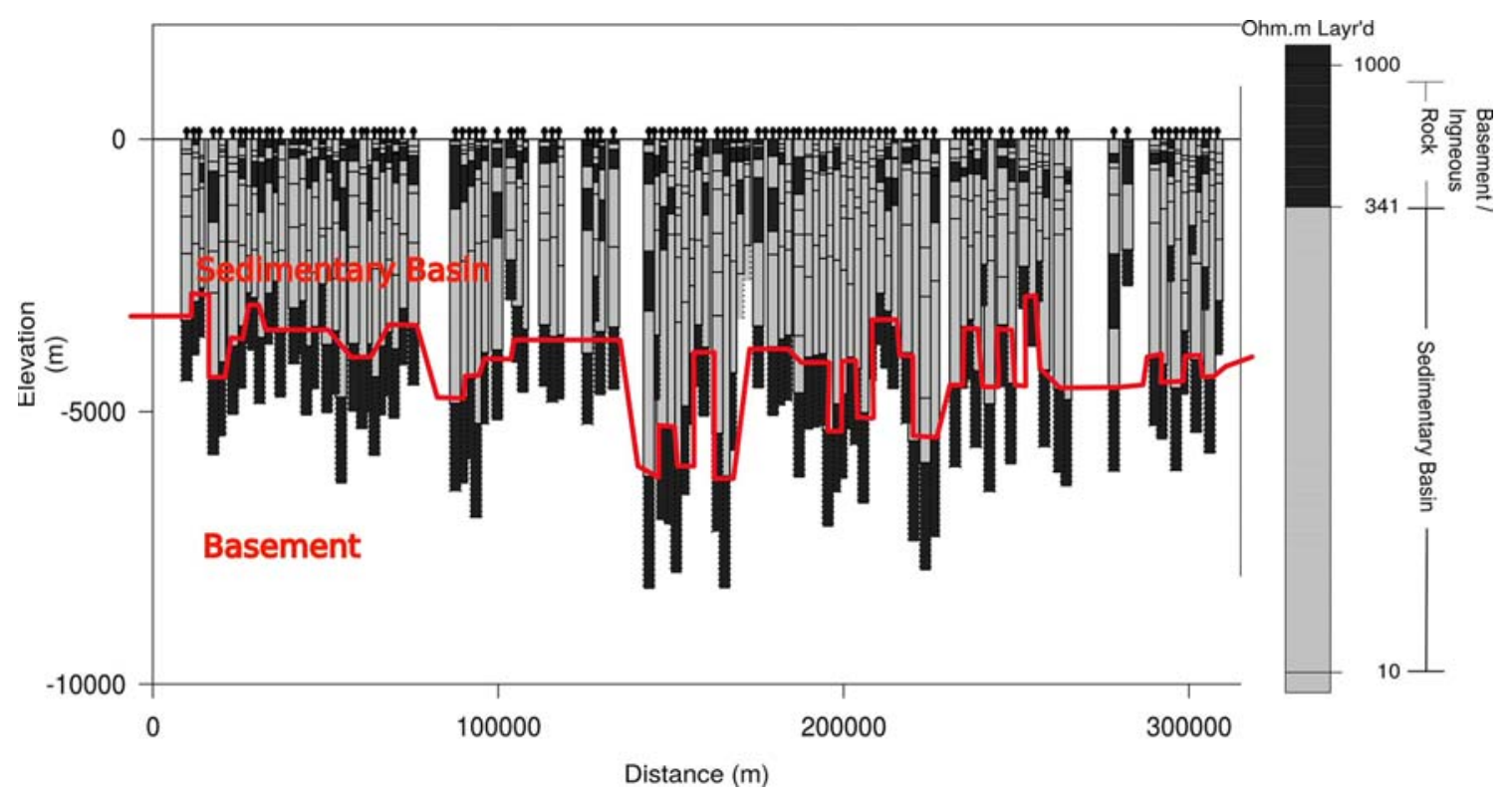

Figure 13 - Interpretation for the basin-basement limit.

hypothetical distribution generated some data, which was compared to the observed gravity profile data (Talwani et al., 1959; Talwani \& Heirtzler, 1960).

The forward model's resulting data was inverted following the methodology described by Marquardt (1963). This procedure was repeated iteratively until the best fit was achieved with an error less than $2 \mathrm{mGal}$.

\section{Regional Model}

Assumpção et al. (2013) published the crustal thickness variations in the continental part and offshore in southeastern Brazil, parts mainly derived from seismological datasets such as deep seismological refraction experiments, receiver function analyses, and surface wave dispersion velocities. The study showed that crustal thickness variations in all Paraná Basin part varied from $37-50 \mathrm{~km}$.

We compiled a dataset from Assumpção et al. (2013) of part of the Paraná Basin spanning our region of study. This interpolated dataset obtained by the kriging method is shown in the isopach map in Figure 14.

Values of the crustal thickness were sampled in the exact location of A-A' profile, and the variations in continental thickness were from $41.3 \mathrm{~km}$ to $42.5 \mathrm{~km}$. This process led us to the conclusion that the Moho has a depth average of $42 \mathrm{~km}$ along the profile. This depth information of applied as a initial starting point to create the boundary for the Moho in our gravimetric inversion regional model.
An mean square error analysis were performed to provide the highest confidence intervals in terms of depth measurements (Fig. 15).

The blue points analyses show that at the SE part of A-A' profile differences between the gravimetric Moho and a seismological Moho points reaches the highest values of depth. The NW part shows depth values differences, between these two geophysical interfaces, decreases.

The regional section was composed of a simple stratified model in which densities from the literature were assigned (Green \& Falloon, 1998; Mooney \& Kaban, 2010; Mariani et al., 2013).

Castro et al. (2016) assign a non-homogeny Precambrian basement with density value ranging from 2569 to $2792 \mathrm{~kg} / \mathrm{m}^{3}$. Mariani et al. (2013) discuss the differences between gravimetric and seismological Moho admitting that the lower and middle part of the crust have a density greater than $2900 \mathrm{~kg} / \mathrm{m}^{3}$. Our results show a continental upper crust with density of $2700 \mathrm{~kg} / \mathrm{m}^{3}$, a lower crust with density of $2940 \mathrm{~kg} / \mathrm{m}^{3}$, and an upper mantle with density fixed at $3350 \mathrm{~kg} / \mathrm{m}^{3}$ (Zevallos et al., 2009; Mooney \& Kaban, 2010; Chaves et al., 2016).

Tree different blocks are represented as follows: a) In the bottom the mantle is composed of peridotite and the density is fixed at $3350 \mathrm{~kg} / \mathrm{m}^{3} ;$ b) On the top represents a lower crust with a density of $2940 \mathrm{~kg} / \mathrm{m}^{3}$; and c) An upper crust with density of $2700 \mathrm{~kg} / \mathrm{m}^{3}$. The Moho interface crust-mantle, starts at an average depth of $42 \mathrm{~km}$ in the model in the Paraná basin depocenter region (Assumpção et al., 2013). 

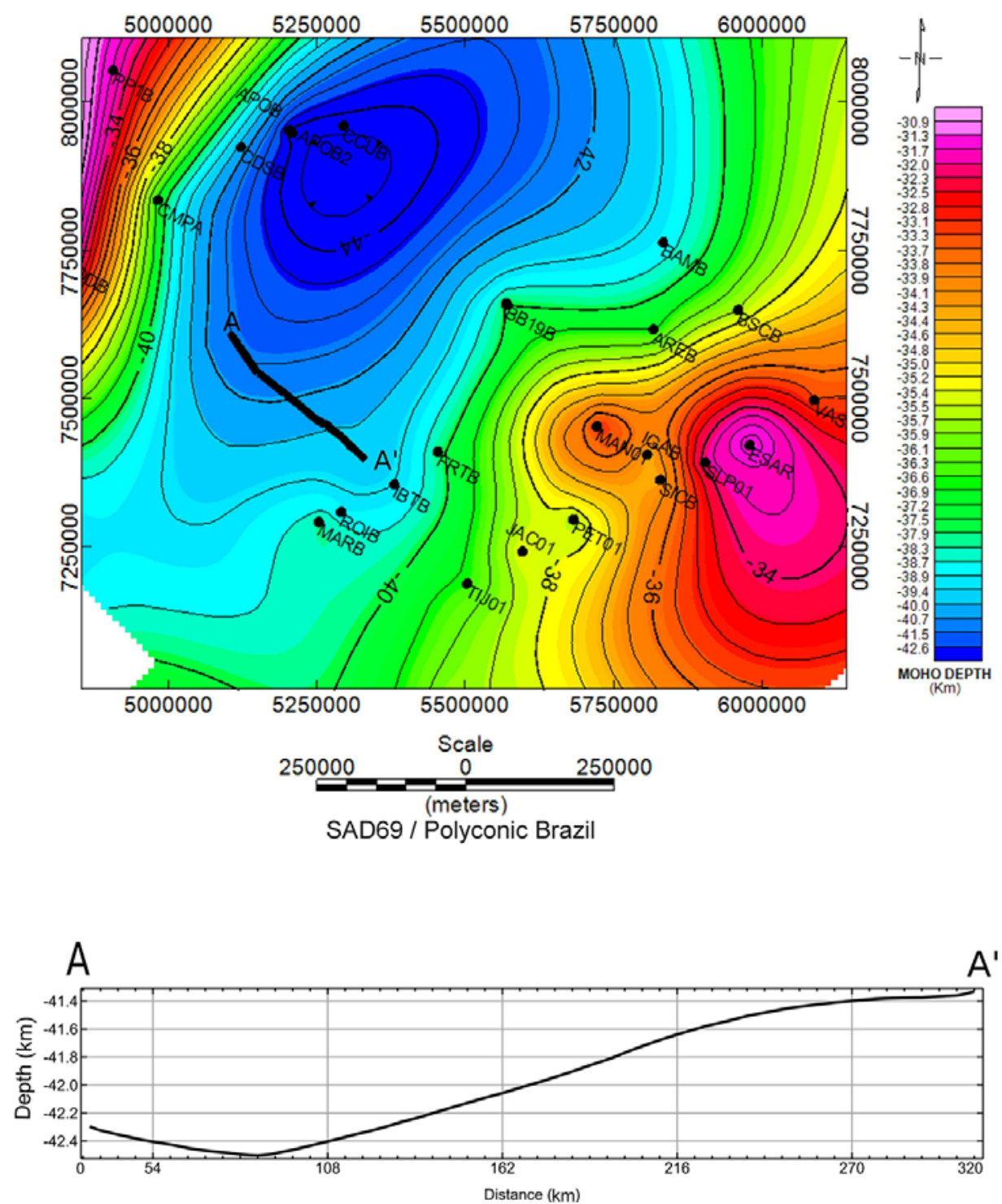

Figure 14 - Isopach map compiled of crustal thickness data (black points) by Assumpção et al. (2013) of Paraná sedimentary basin area. The values in black are the crustal thickness isopach resulting from kriging interpolation of this dataset. The black line indicates the modeled profile.

A non-linear inversion of vertices was used to fit the observed data (Talwani et al., 1959; Talwani \& Heirtzler, 1960; Marquardt, 1963). The procedure resulted in a regional model composed of 3 adjusted blocks presenting a good fit of calculated and measure data with an error of 0.08 mGal (Fig. 16).

The surface which describes the Moho shows smooth depth, ranging from $43 \mathrm{~km}$ to $45 \mathrm{~km}$. On the northwestern limit of the regional line, there is a gravimetric low anomaly, corresponding to having a value of $67 \mathrm{mGal}$. This region of the profile shows a better fit for a $44.14 \mathrm{~km}$ continental crust thickness (Moho's surface)
(Fig. 13). On the other hand, in the central region of the profile, has $63.5 \mathrm{mGal}$ anomaly. In this position, the $2 \mathrm{D}$ gravity model reveals a crustal thickness of $43.29 \mathrm{~km}$. The southeast direction shows a poor increase in crustal thickness that was associated another low Bouguer anomaly. In the regional profile an $82 \mathrm{mGal}$ anomaly coincides with the largest crustal thickness, $45.23 \mathrm{~km}$. In the southwest part the gravimetric low and the increase of the crustal thickness indicates that the crust-mantle interface would be deeper or that it has been an increase of mass. The surface that describes the upper and lower crust contact have an average 
Gravimetric data

- Seismological

MOHO error analysis
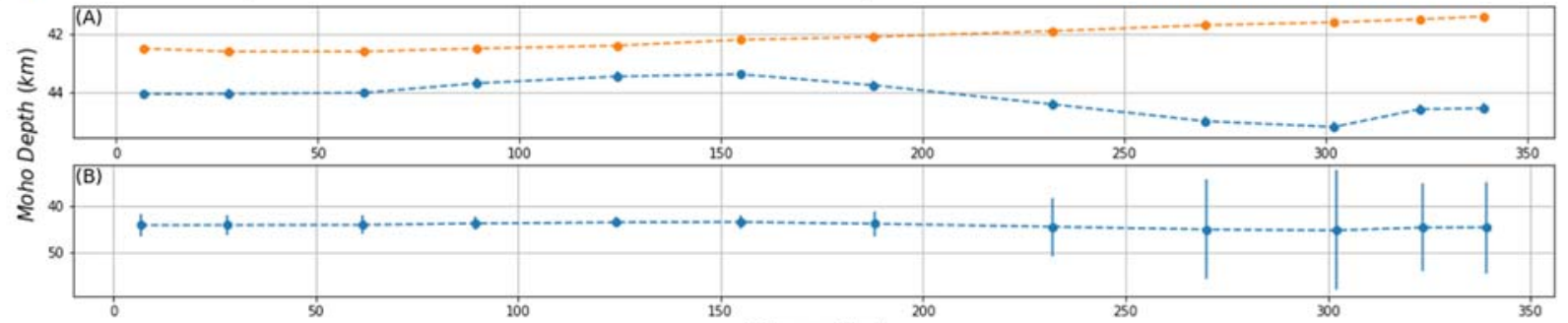

Distance $(\mathrm{km})$

Figure 15 - Moho error analysis between the A-A' profile. The orange line indicates the seismological data provided by Assumpção et al. (2013). The blue line indicates the gravimetric adjustment provided by a initial value of $42 \mathrm{~km}$ depth. (A) shows a comparison between gravimetric and seismological Moho. (B) shows the error analyses for each point of measurement with a respectively error bar.
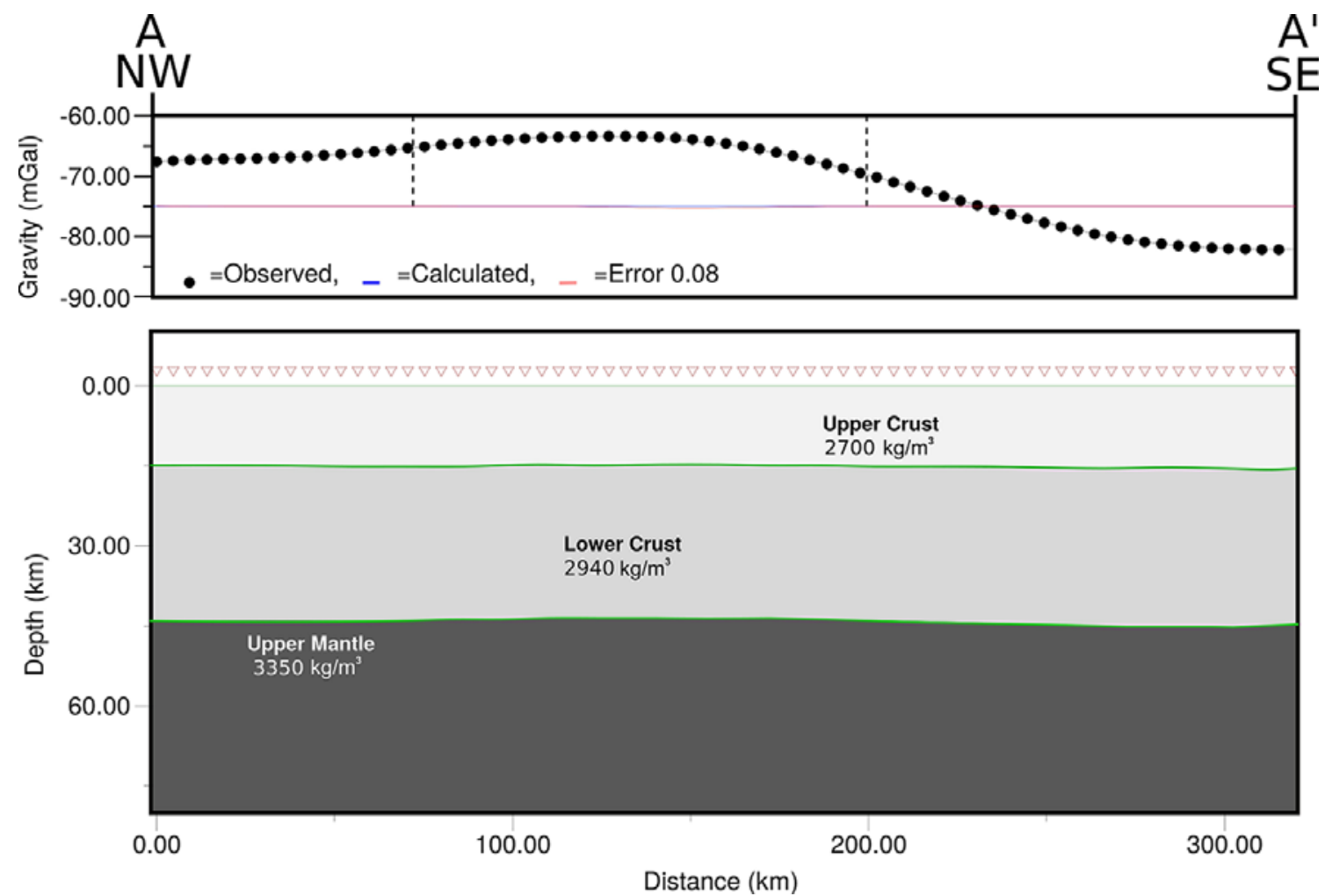

Figure 16 - A three layer model for regional gravimetric anomaly. The upper part of the model shows the upper crust with a density of $2700 \mathrm{~kg} / \mathrm{m}^{3}$, the middle part shows the lower crust with a density of $2940 \mathrm{~kg} / \mathrm{m}^{3}$, and the deep part shows the upper mantle with a density of $3350 \mathrm{~kg} / \mathrm{m}^{3}$. The gravimetric curve shows three different tendencies. The northwestern it presents as relatively gravimetric low, in the center a gravimetric high, and southeast a gravimetric low.

of 15 kilometers depth presenting a smooth geometry. The lower crust's block density has a value of $2940 \mathrm{~kg} / \mathrm{m}^{3}$. And the upper crust's block a density of $2700 \mathrm{~kg} / \mathrm{m}^{3}$.

\section{Final Model}

Geologic models containing different crust and lithospheric geologic structures and having varied densities have been pro- posed by several authors (Xu, 2001; Anderson, 2006; Percival \& Pysklywec, 2007; Irina \& Walter, 2012; Mariani et al., 2013; Castro et al., 2014).

The model is divided into the Upper Mantle, the Lower crust and the Upper crust. Upper crust was divided in two distinct geological domains the first one is the basement was discretized in three blocks interpreted as geotectonic units described by Milani \& Ramos (1998); Mantovani et al. (2005; 2010) and 
Siegfried et al. (2018), and the second one is the sedimentary basin that was subdivided into 6 minors blocks representing it depositional cycle and important formations, in Figure 2.

The 1D MT resistivity inversion model results shown in Figure 13 were the basis for the fitting of the gravity modeling data for the surface, which describes the limit between the crystalline basement and the sedimentary basin. The density model was established by adjusting blocks according to the density values on Table 1 and the total Bouguer anomaly data (Fig. 35).

Table 1 - Densities data for each block used in the model.

\begin{tabular}{|l|c|}
\hline Block Unities & $\begin{array}{c}\text { Density } \\
\left(\mathrm{kg} / \mathrm{m}^{3}\right)\end{array}$ \\
\hline Caiuá Group (CG) & 2200 \\
Serra Geral Formation (SGF) & 2819 \\
Botucatu Formation (BF) & 2388 \\
Gondwana I Supersequence (GSI) & 2593 \\
Paraná Supersequence (PS) & 2451 \\
Ivaí River Supersequence (IRS) & 2665 \\
Apiaí Block (AB) & 2689 \\
Paraná River Block (PRB) & 2687 \\
Paranapanema Block (PB) & 2722 \\
Upper Crust (UC) & 2700 \\
Lower Crust (LC) & 2940 \\
Upper Mantle (UM) & 3350 \\
\hline
\end{tabular}

The density data located in Table 1 from six wells also contributed to mark the initial values for gravity model.

Figure 17 shows the outcrop surface limits of the Caiuá Group (CG) from the Cretaceous, was based on geological maps (Fig. 1). On the NW part of the profile, the Serra Geral Formation (SGF) thickness reaches approximately $1500 \mathrm{~m}$ with a density of $2819 \mathrm{~kg} / \mathrm{m}^{3}$ after inversion. The Botucatu Formation (BF) sandstone is the thickest in the southeastern region of the profile, with a thickness of $100 \mathrm{~m}$ and average density of $2388 \mathrm{~kg} / \mathrm{m}^{3}$. Subsequently, the Gondwana I (GSI) supersequence in the profile's central portion presents about $3000 \mathrm{~m}$ deep and $2593 \mathrm{~kg} / \mathrm{m}^{3}$ density. In the southeastern portion, the Paraná supersequence (PS) comprises a depth of about $4000 \mathrm{~m}$ in the central part and average density of $2451 \mathrm{~kg} / \mathrm{m}^{3}$. The Ivaí River supersequence (IRS) shows the central part of the profile variation of $5000 \mathrm{~m}$ to $6000 \mathrm{~m}$, while the average density is $2665 \mathrm{~kg} / \mathrm{m}^{3}$.

The separation between Paraná Sedimentary Basin and its crystalline basement was obtained through the 1D MT layer model that reached the basement. In the NW sector of the profile, the basement shows variation of depth, fluctuating between 3800 and $6500 \mathrm{~m}$, having horsts and graben-like features that are coincident to the maximum depth in the center of the profile.
The division of the crust turned out to be necessary for the adjustment of the total Bouguer data, fixing blocks based on the tectonic context for the region (Cordani et al., 1984; Milani \& Ramos, 1998; Bizzi et al., 2003; Milani et al., 2007; Rosa et al., 2009). After direct modeling, these blocks had the density parameter inverted.

In the northwest profile a crustal block of the Paraná River Block (PRB) was inserted in the model, allowing to better adjust gravity data with a density of $2687 \mathrm{~kg} / \mathrm{m}^{3}$ (Milani \& Ramos, 1998; Bizzi et al., 2003; Siegfried et al., 2018). The Paranapanema Block (PB) (Milani \& Ramos, 1998; Mantovani et al., 2005; 2010 and Siegfried et al., 2018) with a density of $2772 \mathrm{~kg} / \mathrm{m}^{3}$ was created for the central sector of the profile. The gravity anomaly in the SE sector was adjusted with the insertion of the so-called Apiai Block (AB) (Milani \& Ramos, 1998; Siegfried et al., 2018), having a density of $2689 \mathrm{~kg} / \mathrm{m}^{3}$. Each unities have reached $15 \mathrm{~km}$ depth composing the subdivisions of the Upper crust.

The Lower crust block also present on the total model have a density of $2942 \mathrm{~kg} / \mathrm{m}^{3}$ reaching $42 \mathrm{~km}$ depth. A $3350 \mathrm{~kg} / \mathrm{m}^{3}$ Upper Mantle density ends the adjustment of the total Bouguer anomaly data.

The proposed model showed a good fit with the data, presenting an error of $1.229 \mathrm{mGal}$.

\section{DISCUSSIONS}

Basin's sedimentary portion the average densities of the each formation from the six wells near the profile section A-A' feeds the gravity model. The gravimetric models present great ambiguities, especially when the objective is to delimit the top of the basement of a sedimentary basin. The approach using MT data and $1 \mathrm{D}$ inversion to define the cutting point where the basin-basement resides is innovative. Adjusting the gravimetric data combined with the inversion of the 1D MT (Fig. 12) technique proved to be efficient and responsive to a real complex geological situation.

In the northwest domain section, the model fit was achieved with simple crust and mantle geometry based on previous geological studies. This previous studies indicates that exists a sutured a mobile belt associated with an ancient continent denominated Paraná River Mobile Belt, on the NW part of A-A' profile. The gravimetric high with a -48 mGal anomaly on the central part of the section is associated with this ancient Precambrian continent denominated Paranapanema by Milani \& Ramos (1998) and still recognized by many authors such as Bizzi et al. (2003), Mantovani et al. (2005; 2010) and Siegfried et al. (2018) with a density of $2772 \mathrm{~kg} / \mathrm{m}^{3}$. On the Southeast part, another ancient 

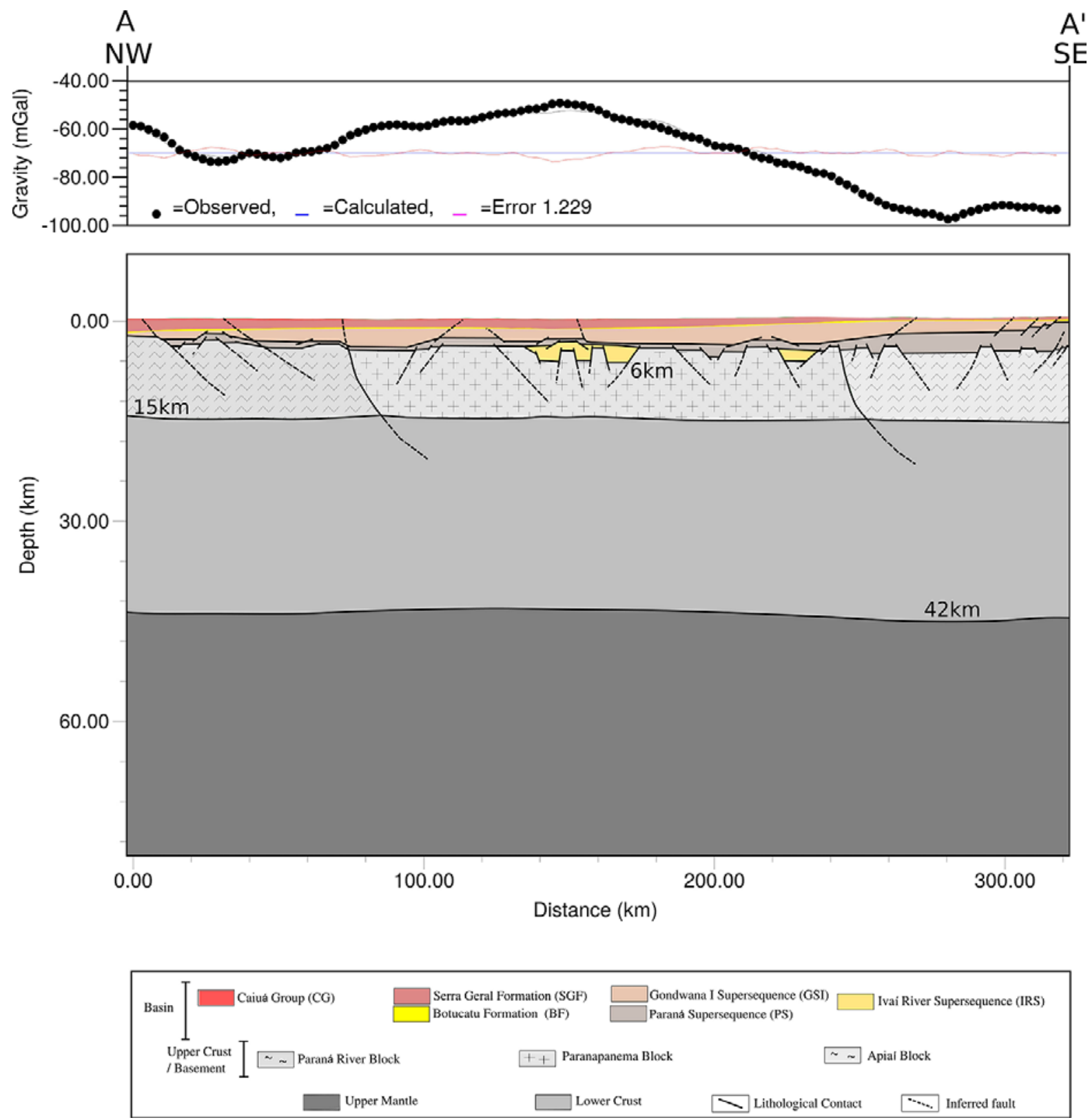

Figure 17 - Interpreted model of total Bouguer anomaly data (A-A' profile). This figure presents a compartimentation of the third upper block of the reginal model into four distinct geotectonic entities: Paraná River Block with a density of $2687 \mathrm{~kg} / \mathrm{m}^{3}$, Paranapanema Block with a density of $2722 \mathrm{~kg} / \mathrm{m}^{3}$, Apiaí Block with a density of $2689 \mathrm{~kg} / \mathrm{m}^{3}$, and on the top the Paraná Sedimentary Basin. Three deepest values of depth of the main reological domains are in evidence. The first one is the basement limit reaching $6 \mathrm{~km}$ depth. Second is the upper crust/lower crust limit reching $15 \mathrm{~km}$ depth. And third is the upper mantle and lower crust limit reaching $42 \mathrm{~km}$ depth.

orogeny holds the total Bouguer anomaly suggesting that subduction's structures help to explain the observed data. Such orogenies conforms the amalgamation of south Gondwana history providing the basement of the Cambrian subsequence history for the Paraná Basin.

The residuals anomalies associated here with the sedimentary basin are corroborated by the model 1D MT and stratigraphic wells, which are associated with the basin depocenter, interpreted by Milani \& Zalán (1999), Milani \& Ramos (1998), Zalán \& Wolf (1987). In the central region, a congruent crustal thinning at the basin's estimated depocenter is interpreted to be associated with an increase in the thickness of the upper mantle. The thinning is directly related to the deeper basin segments, with greater thickness in the center part of the A-A' profile. 
Smalls fluctuations in the crustal thickness could be associated to the Wilson Cycle relative processes that occurred during the Precambrian (Cordani et al., 1984; Ferreira et al., 1993; Milani \& Ramos, 1998; Bizzi et al., 2003; Milani et al., 2007; Rosa et al., 2009).

One hypothesis for the origin of the geometry found for the Moho would have been to be inherited from the subduction and collision processes that occurred during the Precambrian, as well as the processes involving the rupture of the Gondwana supercontinent, which occurred in the Cretaceous (Lefort \& Agarwal, 2002; Anderson, 2006; Irina \& Walter, 2012). The blocks Paraná River, Paranapanema, and Apiaí were bonded by these bygone tectonic processes. These oceanic and continental crust complex system collisions that occurred after the stabilization at the end of the Brasiliano Cycle would serve as the Paraná Basin crystalline basement, which would have its sedimentary package developed throughout the Phanerozoic (Zalán \& Wolf, 1987).

Mariani et al. (2013) indicate that there is a difference between the gravimetric Mohorovicic interface and the correspondent seismological surface. This difference between the northern and southern sectors of Paraná Basin on the seismological Moho is significantly deeper than expected from the gravity analyses, on the A-A' profile, as shown on Figure 15. This difference only can be explained by increasing the total volume of mass on the Lower crust. In the final model this difference was justified by choosing a higher value of $2940 \mathrm{~kg} / \mathrm{m}^{3}$.

The surplus of mass it is associated with an underplatting magmatism, in the sense that the melting basalt material is emplaced partly as a flood basalt at the top of the crust, but some part inside the crust. Densities greater than $2900 \mathrm{~kg} / \mathrm{m}^{3}$ are densities higher to the referenced crust in accordance to Mariani et al. (2013) and Chaves et al. (2016). This dense material was I0calized at the top of the Lower crust in the form of sills, and entered into cracks or trough geological faults at the bottom of the Upper crust, increasing the total volume of the crust. And on the top of this process the flowing basalt that pass trough the cracks generates the Serra Geral Formation.

According to the interpretation of the basin of the Paraná basin by (Milani \& Ramos, 1998), there are three main crustal blocks in the position of our study profile, Rio Paraná Block and Parapanema Block and Apiaí Block. Data shows three main anomalies being two gravimetric lows marked by blocks PRB and $A B$ (Fig. 14), associated with the two mobile belts identified by Milani \& Ramos (1998), PRB and AB, and a gravimetric high associated with PB.

\section{CONCLUSIONS}

Paraná Sedimentary Basin presents a very complex geologic history. History composed by a series different of tectonic process including amalgamation and breakup of continents and magmatic underplatting. Dynamic changes under this different environment conditions induces the movement over the depositions processes of sediments previous established, over time. Presenting a hypothetical gravimetric model restricted by a series of complementary data this article aims to define a geophysical and geological section. Those restrictions use of several integrated geophysical techniques that allowed the validation of an interpreted geological model, restricting, at least partially, the usual ambiguities when only one data type is used. The $2 \mathrm{D}$ geophysical model obtained through the gravimetric data adjustment showed an average error of 1,229 mGal. Such errors can be considered low when associated with sedimentary and crystalline rock density uncertainties and the modeled bodies' geometry.

An innovative technique presented here is the $1 \mathrm{D} \mathrm{MT}$ inversions that generated a 1D composed section that mark the interface between the sedimentary basin and the Upper crust. The results show that this limit was well marked to $z$ directions, but did not defined the $x$ directions on inverted model. Lateral correlation could carry ambiguities correlated to the $x$ directions although gravity data showed good fit.

New 2D and 3D MT data inversions show divisions on the Upper crust and with the basement depth that corroborate the 1D model and final gravimetric model (Maurya et al., 2017).

The regional model adjustment (Fig. 16) produce a $15 \mathrm{~km}$ depth Upper crust with a higher density than expected. The density of $2940 \mathrm{~kg} / \mathrm{m}^{3}$ only can be explained by a surplus of mass inherited by a gigantic geologic process associated with Gondwanaland's breakup at the beginning of the Wilson Cycle. A smooth $42 \mathrm{~km}$ Moho is also correlated to this ancient tectonics already isostatistically compensated (Zevallos et al., 2009; Mooney \& Kaban, 2010; Mariani et al., 2013; Chaves et al., 2016). Interfaces of $42 \mathrm{~km}$ and $15 \mathrm{~km}$ were justified by defining density of $3350 \mathrm{~kg} / \mathrm{m}^{3}$ for the upper mantle, $2940 \mathrm{~kg} / \mathrm{m}^{3}$ for the Lower crust and $2700 \mathrm{~kg} / \mathrm{m}^{3}$ for the Upper crust initially. Regional separation based on a wavelength cutoff shows no tendency when compared to other separations methodologies as polynomial filtering.

The proposed final model (Fig. 17) shows three main interfaces depth. The first one with a $42 \mathrm{~km}$ depth marking the limit of the Upper Moho and the Lower crust. The second one is the limit with a $15 \mathrm{~km}$ depth showing the interface of the Lower crust and the Upper crust. And the third with a $6 \mathrm{~km}$ depth marks the sedimentary basement surface's. The Paranapanema 
Block, Paraná River Block, Apiaí Block were and divisions by blocks adopted for the Upper crust, in the basement domain. The sedimentary basin domain six block were created. They are the Caiuá Group, Serra Geral Formation, Botucatu Formation, Gondwana I Supersequence, Paraná Supersequence, and the Ivaí River Supersequence.

Paranapanema Block is associated with a Cratonic unit and have a final density value of $2722 \mathrm{~kg} / \mathrm{m}^{3}$ (see Table 1) and have a curved contacts between the two surrounding mobile belts dating from Brasiliano, Apiai and Paraná River Mobile Belts, with density values of $2689 \mathrm{~kg} / \mathrm{m}^{3}$ and $2687 \mathrm{~kg} / \mathrm{m}^{3}$ respectively. The geometry of this contacts justified the abrupt inclination on the gravimetric anomaly curve before reaches gravimetric high (Figs. 16 and 17). The sedimentary basin domain presents six blocks with densities (see Table 1) calculated in direct drilling process, acquired by well data. The SE part of A-A' profile (Fig. 17) shows a lateral thinning layer for the Ponta Grossa Formation which is inserted on the context of the Ponta Grossa Arch. Ponta Grossa Arch have uplifts the downward layers providing the source area for weathering and erosion.

An implication of this article is the importance that previous studies on geology have to solve or reduce geophysical ambiguities aligned with a series of geophysical complementary methods as magnetotellurics, wells and seismology. Nevertheless more than one model fits the observed gravimetric data. The final fitted model's RMS shows good result indicating that the proposed model explains the observed gravimetric data and have accordance with the latest interpretation of the geological events that have occurred during the formation of Paraná Basin.

\section{ACKNOWLEDGEMENTS}

The authors have special thanks to Agência Nacional do Petróleo, Gás Natural e Biocombustíveis (ANP - National Agency of Petroleum, Natural Gas and Biofuels - Brazil) that provided the geophysical data and Observatório Nacional (ON) with the computational infrastructure.

\section{REFERENCES}

ANDERSON DL. 2006. Speculations on the nature and cause of mantle heterogeneity. Tectonophysics - Elsevier, 416, 7-22, doi: 10.1016/j.tecto.2005.07.011.

ÁRNASON K. 2008. The magnetotelluric static shift problem. ÍSOR Iceland GeoSurvey, Reykjavik, report, ISOR-08088, 17.

ASSUMPÇÃO M, BIANCHI M, DIAS F, NASCIMENTO R \& DROUET S. 2013. Crustal thickness map of Brazil: Data compilation and main features. Journal of South American Earth Sciences, 43: 74-85, doi: 10.1016/j.jsames.2012.12.009.

BACKUS G. 1970. Inference from inadequate and inaccurate data, I*, University of California (La Jolla), 65(1): 1-7.

BELTRÃO JF, SILVA JBC \& COSTA JC. 1991. Robust polynomial fitting method for regional gravity estimation. Geophysics, 56(1): 80-89, doi: 10.1190/1.1442960.

BIZZI AL, SCHOBENHAUS C, VIDOTTI RM \& GONÇALVES. 2003. Geologia, Tectônica e Recursos Minerais do Brasil: texto, mapas e SIG. CPRM - Serviço Geológico do Brasil, Brazil.

BOLOGNA M, NUNES H, PADILHA A, VITORELLO I \& PÁDUA M. 2013. Anomalous electrical structure in the northwestern Paraná Basin, Brazil, observed with broadband magnetotellurics. Journal of South American Earth Sciences, 42: 74-82.

BORGHI L. 2002. A Bacia do Paraná. Anuário do Instituto de Geociências - IGEO, Departamento de Geologia, Universidade Federal do Rio de Janeiro, Brazil. 239 pp.

CASTRO D, FUCK R \& PHILLIPS J. 2014. Crustal structure beneath the paleozoic Parnaíba basin revealed by airbone gravity and magnetic data, Brazil. Tectonophysics, 614: 128-145, doi:10.1016/j.tecto.2013.12.009.

CASTRO DL, BEZERRA FH, FUCK RA \& VIDOTTI RM. 2016. Geophysical evidence of pre-sag rifting and post-rifting fault reactivation in the Parnaíba basin, Brazil. Solid Earth, 7: 529-548, doi: 10.5194/se-7-5292016.

CHAVES C, USSAMI N \& RITSEMA J. 2016. Density and P-wave velocity structure beneath the Paraná Magmatic Province: Refertilization of an ancient lithospheric mantle. Geochemistry, Geophysics, Geosystems. AGU Publications, S1, 3054-3058, doi: 10.1002/2016GC006369.

CONSTABLE SC, PARKER RL \& CONSTABLE CG. 1987. Occam's inversion: A practical algorithm for generating smooth models from electromagnetic sounding data. Geophysics, 52(3): 289-300.

CORDANI UG, BRITO NEVES BB, FUCK RA, PORTO R, THOMAS A \& CUNHA FMB. 1984. Estudo preliminar de integração do pré-cambriano com os eventos tectônicos das bacias sedimentares brasileiras. Ciência Técnica do Petróleo, 70 pp.

DETZEL H, ASSUMPÇÃO M, BIANCHI M \& PIRCHINER M. 2015. Intraplate seismicity in mid-plate South America: correlations with geophysical lithospheric parameters. Geological Society, Special Publications London, 432: 73-90, doi:10.1144/SP432.5.

EGBERT GD \& BOOKER JR. 1986. Robust estimation of geomagnetic transfer functions. Geophys. J. Royal Astron. Soc., 87: 173-194, doi: 10.1111/j.1365-246X.1986.tb04552.x.

FERREIRAFJF, BUONORAMPP \& BRITO NEVES BB. 1993. Interpretação de um trato do embasamento da Bacia do Paraná com base em parâmetros geofísicos dos terrenos expostos e na aplicação de filtragens 
aeromagnéticas. In: International Congress of the Brazilian Geophysical Society, 3., 1993, Rio de Janeiro, RJ, Brazil: SBGf, v. 2, p. 814-819.

FIGUEIREDO I. 2008. Heterogeneous crust and upper mantle across the SE Brazilian Highlands and the relationship to surface deformation as inferred from magnetotelluric imaging. Journal of Geophysical Research, 113: 1-15, doi:10.1029/2007JB005108.

FRANÇA G \& ASSUMPÇÃO M. 2004. Crustal structure of the Ribeira fold belt, SE Brazil, derived from receiver functions. Journal of South America Earth Science, 16: 743-758, doi: 10.1016/j.jsames.2003.12.002.

GAMBLE T, GOUBAU W \& CLARKE J. 1979. Magnetotellurics with a remote magnetic reference. Geophysics, 44(1): 53-68.

GREEND \& FALLOONT. 1998. Pyrolite: A Ringwood conceptand its current expression. In: JACKSON I (Ed). The Earth's Mantle: composition, structure and evolution. Cambridge University Press, UK, 2 ed., 567 pp.

HAWKESWORTH C, GALLAGHER K, KIRSTEIN L, MANTOVANI M, PEATE D \& TURNER S. 2000. Tectonic controls on magmatism associated with continental break-up: an example from the Paraná-Etendeka Province. Earth and Planetary Science Letters, 179: 335-349.

HEISKANEN WA \& MORITZ H. 1965. Physical Geodesy. W.H. Freeman and Company, San Francisco and London, 365 pp.

IRINA M \& WALTER D. 2012. On the relations between cratonic lithosphere thickness, plate motions, and basal drag. Tectonophysics - Elsevier, 358: 211-231.

JACKSON D. 1979. The use of a priori data to resolve non - uniqueness in linear inversion. Geophysical Journal Royal Astronomy Society, 57: 137-157.

JONES AG. 1988. Static shift of magnetotelluric data and its removal in a sedimentary basin environment. Geophysics, 53: 967-978, doi: 10.1190/1.1442533.

KANE MF. 1962. A comprehensive system of terrain corrections using digital computer. Geophysics, 27: 455-462, doi: 10.1190/1.1439044.

LA FEHR TR. 1991. An exact solution for the gravity curvature (Bullard B) correction. Geophysics, 56: 1179-1184, doi: 10.1190/1.1443138.

LA TERRA EF, TUPINAMBÁ M \& FONTES SL. 2015. Modelado gravimétrico de una sección entre el margen continental del sudeste de Brasil y el area emergida adyacente, Geociencias Aplicadas Latinoamericanas, 2: 1-16, doi: 10.3997/2352-828120150004.

LEFORT J \& AGARWAL B. 2002. Topography of the Moho undulations in France from gravity data: their age and origin. Tectonophysics, Elsevier, 350: 193-213.

LLOYD S, LEE S, FRANÇA G \& ASSUMPÇÃO M. 2010. Moho map of South America from receiver functions and surface waves. Journal Geophysical Research, 115: 1-12, doi: 10.1029/2009JB006829.
LONGMAN IM. 1959. Formulas for computing the tidal accelerations due to the moon and the sun. Journal of Geophysical Research, 64(12): 2351-2355.

MANTOVANI MSM, QUINTAS, MC, SHUKOWSKY W, BRITO N \& BENJAMIN B. 2005. Delimitation of the Paranapanema Proterozoic block: A geophysical contribution. Episodes, 28(1): 18-22.

MANTOVANI MSM, BRITO N \& BENJAMIN B. 2010. The Paranapanema Lithospheric Block: Its Nature and Role in the Accretion of Gondwana. In: GAUCHER C, SIAL A, HALVERSON GP \& FRIMMEL HE. Neoproterozoic-cambrian tectonics, global change and evolution: a focus on south western Gondwana. Elsevier. p. 257-272.

MARIANI P, BRAITENBERG C \& USSAMI N. 2013. Explaining the thick crust in Paraná basin, Brazil, with satellite GOCE gravity observations. Journal of South American Earth Science, 45: 209-223, doi: 10.1016/j.jsames.2013.03.008.

MARQUARDT WD. 1963. An algorithm for least-squares estimation of nonlinear parameters. Journal of the Society for Industrial and Applied Mathematics, 11(2): 431-441, doi:10.1137/0111030.

MAURYA, VP, FONTES SL, MEJU MA, LA TERRA EF, MIQUELUTTI LG, TAVEIRA D \& FIGUEIREDO I. 2017. 3D magnetotelluric imaging of basalt-covered sediments and fragmented basement of central Paraná Basin, SE Brazil. In: 6th International Symposium on Three-Dimensional Electromagnetics, Berkeley, California, USA, March 28-30.

MEJU MA. 1994. Geophysical Data Analysis: Understanding Inverse Problem Theory and Practice. Society of Exploration Geophysicists, Course Notes Series, Vol. 6, SEG Publishers, Tulsa, Oklahoma, 269 pp.

MENEZES PL \& TRAVASSOS JM. 2004. EM modeling of the centralnorthern portion of the Ponta Grossa Arch, Paraná Basin, Brazil. Physics of the Earth and Planetary Interiors, 150: 145-158.

MILANI EJ \& RAMOS VA. 1998. Orogenias paleozóicas no domínio sulocidental do Gondwana e os ciclos de subsidência da Bacia do Paraná. Brazilian Journal of Geology, 28(4): 473-484.

MILANI E \& ZALÁN P. 1999. An outline of the geology and petroleum systems of the Paleozoic interior basins of South America. Episodes, 22(3): 199-205.

MILANI E, SPADINI A, TERRA G, SILVA E \& BUENO G. 2007. Boletim de Geociências da Petrobras, Cenpes, 15. 571 pp.

MOONEY WD \& KABAN MK. 2010. The North American upper mantle: Density, composition, and evolution. Journal of Geophysical Research, 115: 1-24, doi: 10.1029/2010JB000866.

MOTA C. 2008. Estudos Geológicos e Gravimétricos do Complexo Marapicu-Gericinó Mendanha (Rio de Janeiro). Master Dissertation, Universidade do Estado do Rio de Janeiro, Faculdade de Geologia, Brazil. $128 \mathrm{pp}$.

MWAKIRANI R, SIMIYU C \& GICHIRA J. 2012. Application of transient electromagnetic in static shift correction for magnetotellurics data case 
study: Paka geothermal prospect in Kenya. GRC - Transactions, 36: 1013-1016.

NAGY D. 1966. The gravitational attraction of a right rectangular prism. Geophysics, 31(2): 362-371, doi: 10.1190/1.1439779.

PADILHA A, VITORELLO I, ANTUNES C \& PÁDUA MB. 2015. Imaging three-dimensional crustal conductivity structures reflecting continental flood basalt effects hidden beneath thick intracratonic sedimentary basin. Journal of Geophysical Research, 120: 4702-4719, doi: 10.1002/2014JB011657.

PERCIVAL J \& PYSKLYWEC R. 2007. Are archean lithospheric keels inverted? Earth and Planetary Science Letters, Earth and Planetary Science Letters, 254: 393-403, doi:10.1016/j.epsl.2006.11.047.

QUINTAS MC. 1995. 0 Embasamento da Bacia do Paraná: Reconstrução Geofísica de seu Arcabouço. PhD Thesis, USP-Universidade de São Paulo, Brazil, 205 pp.

QUINTAS MC, MANTOVANI MSM \& ZALÁN PV. 1999. Contribuição ao Estudo da Evolução Mecânica da Bacia do Paraná. Revista Brasileira de Geociências, 29(2): 217-226.

RODI W \& MACKIE R. 2001. Nonlinear conjugate gradients algorithm for 2-D magnetotelluric inversion. Geophysics, 66: 174-187, doi: 10.1190/1.1444893.

ROSA ML, TOMAZELLI LJ, COSTA AFU \& BARBOZA EG. 2009. Integração de métodos potenciais (gravimetria e magnetometria) na caracterização do embasamento da região sudoeste da Bacia de Pelotas, sul do Brasil. Brazilian Journal of Geophysics, 27(4): 641-657.

SCHNEIDER R, MUHLMANN H, TOMMASI E, MEDEIROS R, DAEMON R \& NOGUEIRA A. 1974. Revisão estratigráfica da Bacia do Paraná. In: Anais do Congresso Brasileiro de Geologia, 4., Brazil.

SIEGFRIED S, MIGUEL ASB, PEDRO 0 \& SEBASTIAN 0. 2018. Geology Southwest Gondwana. Springer International Publishing. 687 pp.

SIMPSON F \& BAHR K. 2005. Practical Magnetotellurics. Cambridge University Press. 254 pp.

SPECTOR A. 1968. Spectral analysis of aeromagnetic maps. PhD Thesis, Department of Physics, University of Toronto, Canada, 239 pp.

SPECTOR A \& BHATTACHARYYA BK. 1966. Energy density spectrum and autocorrelation function of anomalies due to simple magnetic models. Geophysical Prospecting, 14(3): 242-272, doi: 10.111/j13652478.1966tb01760.

SPECTORA \& GRANT FS. 1970. Statistical models for interpreting aeromagnetic data. Geophysics, 35(2): 293-302.
STERNBERG B, WASHBURNE J \& PELLERIN L. 1988. Correction for the static shift in magnetotellurics using transient electromagnetic soundings. Geophysics, 53(11): 1459-1468, doi: 10.1190/1.1442426.

TALWANI M \& HEIRTZLER J. 1960. Rapid computation of gravitational attraction of three-dimensional bodies of arbitrary shape. Geophysics, 25(1): 203-250, doi: 10.1190/1.1438687.

TALWANI M, WORZEL JL \& LANDISMAN M. 1959. Rapid gravity computations for two-dimensional bodies with application to the Mendocino submarine fracture zone. Journal of Geophysical Research, 64(1): 49-59.

TELFORD WM, GELDART LP, SHERIFF RE \& KEY DA. 1998. Applied Geophysics. 5 ed., Cambridge University Press, 860 pp.

USSAMI N, KOLISNYK A, RAPOSO MIB, FERREIRA FJF, MOLINA EC \& ERNESTO M. 1991. Detectabilidade magnética de diques do arco de Ponta Grossa: um estudo integrado de magnetometria terrestre e aérea e magnetismo de rocha. Brazilian Journal of Geology, 21(4): 317-327.

VAIL PR, MITCHUM RM JR \& THOMPSON SAM. 1977. III. Seismic Stratigraphy and Global Changes of Sea Level: Part 4. Global Cycles of Relative Changes of Sea Level: Section 2. Application of Seismic Reflection Configuration to Stratigraphic Interpretation, 1977, 83-97.

VIDOTTI R, EBINGER C \& FAIRHEAD J. 1998. Gravity signature of the western Paraná basin, Brazil. Earth and Planetary Science Letters, 159: 117-132.

VOZOFF K. 1991. The Magnetotelluric Method. Electromagnetic Methods in Applied Geophysics, Society of Exploration Geophysicists, chapter 8, 641-712, doi: 10.1190/1.9781560802686.

WON IJ \& BEVIS M. 1987. Computing the gravitational and magnetic anomalies due to a polygon: Algorithms and Fortran subroutines. Geophysics, 52: 232-238.

XU X. 2001. Thermo-tectonic destruction of the Archaean lithospheric keel beneath the Sino-Korean Craton in China: evidence, timing and mechanism. Phys. Chem. Earth (A), 26(9): 747-757.

ZALÁN PV \& WOLF S. 1987. Tectônica e sedimentação da Bacia do Paraná. In: Simpósio Sul-Brasileiro de Geologia,SBG, 3., Atas, CuritibaPR., Brazil, 1, 441-477.

ZEVALLOS I, ASSUMPÇÃO M \& PADILHA AL. 2009. Inversion of teleseismic receiver function and magnetotelluric sounding to determine basement depth in the Paraná Basin, SE Brazil. Journal of Applied Geophysics, 68: 231-242, doi: 10.1016/j.jappgeo. 